American University Washington College of Law

Digital Commons @ American University Washington College of

Law

Articles in Law Reviews \& Other Academic Journals

Scholarship \& Research

Winter 2020

Publicly Charged: A Critical Examination of Immigrant Public Benefit Restrictions

Cori Alonso-Yoder

Follow this and additional works at: https://digitalcommons.wcl.american.edu/facsch_lawrev

Part of the Immigration Law Commons 


\section{American University Washington College of Law}

From the SelectedWorks of Cori Alonso-Yoder

February, 2020

\section{Publicly Charged: A Critical Examination of Immigrant Public Benefit Restrictions}

Cori Alonso-Yoder, American University Washington College of Law 


\title{
Publicly Charged: A CRitical EXAmination OF IMMIGRANT PUBLIC BENEFIT RESTRICTIONS
}

\author{
CORI ALONSO-YODER ${ }^{\dagger}$
}

\begin{abstract}
Since the early days of the Trump Administration, reports of the President's controversial and dramatic immigration policies have dominated the news. Yet, despite the intensity of this coverage, an immigration policy with far broader implications for millions of immigrants and their U.S.citizen family members has dodged the same media glare. By expanding the definition of who constitutes a "public charge" under immigration law, the Administration has begun a process to restrict legal immigration and chill the use of welfare benefits around the country. The doctrine of public charge exclusion developed from colonial times and has reemerged in Trump Administration policies as a means to curtail legal immigration through executive action. While other commentators have questioned the racial implications of welfare reform as they affect Black families, the discriminatory animus behind efforts to kick immigrant families off the rolls has yet to be explored.

Drawing on critical examinations of welfare reform that locate raceconscious motivations in the figure of the "welfare queen," the Article examines the rhetorical appeal of the "anchor baby." By questioning the legitimacy of these children's birthright citizenship and their use of benefits, proponents of immigration restriction reveal that their exclusionary policies are motivated less by concerns of immigration or economic status and more by fears of racial difference. When viewed in the context of political and demographic historical trends, the public charge doctrine emerges as a facially neutral pretext for legal discrimination that must be left firmly in the past.
\end{abstract}

"I'd much rather find out whether or not anchor babies are citizens because a lot of people don't think they are. We're going to test it out."

-Donald Trump (August 9, 2015)

$\dagger \quad$ Practitioner in Residence in the Immigrant Justice Clinic at American University Washington College of Law. I wish to thank Jayesh Rathod, Sameer Ashar, Sarah Sherman-Stokes, Laila Hlass, Claire Thomas, and Ernie Collette who offered substantive feedback on this Article at the 2018 NYU Clinical Law Review Writers' Workshop. I would also like to recognize the research assistance of Dalal Hillou, JD Lefrere, and Katia Barron. Any errors are my own.

1. Reena Flores, Donald Trump: “Anchor Babies" Aren't American Citizens, CBS NEWS (Aug. 19, 2015, 10:44 AM), https://www.cbsnews.com/news/donald-trump-anchor-babies-arentamerican-citizens/. 


\section{TABLE OF CONTENTS}

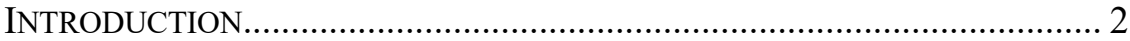

I. POVERTY-BASED LEGAL RESTRICTIONS ON IMMIGRATION.................... 6

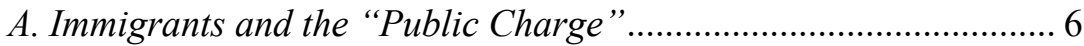

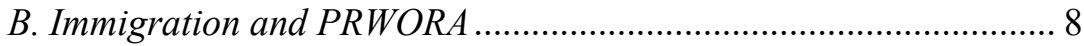

II. DECONSTRUCTING ENTITLEMENTS THROUGH POLITICAL

RHETORIC AND LEGISLATION ............................................................. 9

A. Racism, PRWORA, and the "Welfare Queen"............................... 9

B. Nativism, PRWORA, and the "Anchor Baby" ............................ 12

1. Historical Discrimination Behind

Immigration-Status-Based Welfare Restrictions..................... 14

2. The Policies and Politics of the "Anchor Baby" ...................... 19

3. Defining Birthright Citizenship and Who is "American" ........ 21

C. Birtherism, Executive Action on Immigration, and

President Obama ........................................................................ 23

III. PRESIDENT TRUMP'S EFFORTS TO LIMIT IMMIGRATION AND

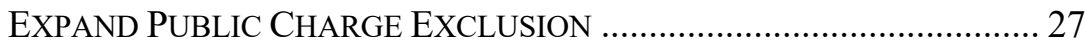

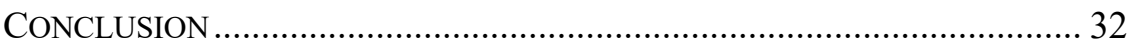

\section{INTRODUCTION}

In the early months of 2018, several media outlets reported on leaked Department of Homeland Security (DHS) draft policies, designed to restrict immigration to the United States based on public benefit use. ${ }^{2}$ These drafts set out a series of policy changes that dramatically expanded the consequences for legal immigrants' interactions with state, local, and federal social safety net programs. ${ }^{3}$ Unlike existing regulations that create penalties for immigrants' personal use of certain public benefits, the draft regulations proposed denial of visa status based on the public benefit use of immigrants' U.S.-citizen children. The proposal also expanded the number and kinds of programs that immigration officials can consider in deeming a noncitizen "likely to become a public charge."4 The Migration Policy Institute estimated that the proposal could affect 9.2 million U.S.citizen children and increase the percentage of noncitizens subject to visa denial from the current $3 \%$ to a staggering $47 \%{ }^{5}$

2. Dara Lind, Exclusive: Trump's Draft Plan to Punish Legal Immigrants for Sending USborn Kids to Head Start, VoX (Feb. 8, 2018, 7:37 PM), https://www.vox.com/2018/2/8/16993172/trump-regulation-immigrants-benefits-public-charge; Nick Miroff, Trump Proposal Would Penalize Immigrants Who Use Tax Credits and Other Benefits, WASH. POST (Mar. 28, 2018, 12:10 PM), https://www.washingtonpost.com/world/national-security/trumpproposal-would-penalize-immigrants-who-use-tax-credits-and-other-benefits/2018/03/28/4c6392e 02924-11e8-bc72-077aa4dab9ef_story.html?noredirect=on\&utm_term=.8712a664c565.

3. Lind, supra note 2; Miroff, supra note 2.

4. Lind, supra note 2; Miroff, supra note 2.

5. Jeanne Batalova et al., Migration Pol'y Inst., Chilling Effects: The EXPeCted Public Charge Rule and Its ImpaCt On Legal ImMigrant Families' Public Benefits Use 1, 4 (2018). 
After months of leaks and modifications, the Administration finally issued its notice of proposed rulemaking with the official version of the proposed rule on October 10, 2018. ${ }^{6}$ In its request for public comment, DHS received over 266,000 comments on the proposal. ${ }^{7}$ In the end, some of the most problematic aspects of the earlier, leaked draft rule disappeared from the final proposal. Among these were proposed provisions penalizing immigrant parents for their children's authorized use of education, health, and nutrition benefits. Though these provisions were not present in the final proposal, their inclusion in the earlier draft laid bare the Administration's hostility toward immigrant families.

Efforts to change the public charge rule reflect a natural progression of the Trump immigration policy platform. In comments submitted to the government regarding the proposed changes, the Catholic Legal Immigration Network situated the proposal in a timeline of the Trump Administration's broader campaign against legal immigration and family unity. ${ }^{8}$ Those actions included: the ban on entry for nationals of certain Muslimmajority nations (the so-called Muslim ban); rescission of protections under the programs for Deferred Action for Childhood Arrivals (DACA) and Temporary Protected Status (TPS); historically high restrictions on the admission of refugees; and the Administration's "zero tolerance" policy separating parents and children at the U.S. Southern Border.'

In early 2017, a leaked Executive Order-similar in essence to the leaked DHS draft policies — outlined a policy titled: "Protecting Taxpayer Resources by Ensuring Immigration Laws Promote Accountability and Responsibility." ${ }^{10}$ Dated just three days after President Trump's inauguration, the leaked order coincided with a flurry of executive orders that the new Administration issued in its first week in office. ${ }^{11}$ While President Trump signed and promulgated other controversial orders on immigration, the draft order remained merely a leak. Regardless, the draft proposed a dramatic and expansive new approach to evaluating immigrant use of public benefits, portending the October 2018 rulemaking. The draft order proposed reporting on specific issues, including "the cost to American taxpayers of providing means-tested public benefits . . . to households headed

6. Inadmissibility on Public Charge Grounds, 83 Fed. Reg. 51,114 (proposed Oct. 10, 2018) (to be codified at 8 C.F.R. pts. 103, 212-14, 245, 248).

7. Inadmissibility on Public Charge Grounds, REgulations.gOv (Nov. 17, 2019, 3:59 PM ET), https://www.regulations.gov/docket?D=USCIS-2010-0012.

8. Catholic Legal Immigr. Network InC., Comments in Response to Proposed RULEMAKING: INADMISSIBILITY ON PUBLIC CHARGE GROUNDS (2018).

9. Id.

10. Abigail Hauslohner \& Janell Ross, Trump Administration Circulates More Draft Immigration Restrictions, Focusing on Protecting U.S. Jobs, WASH. POST (Jan. 31, 2017), https://www.washingtonpost.com/world/national-security/trump-administration-circulates-more-draft-immigration-restrictions-focusing-on-protecting-us-jobs/2017/01/31/38529236-e741-11e6-80c2$30 \mathrm{e} 57 \mathrm{e} 57 \mathrm{e} 05 \mathrm{~d}$ story.html? noredirect $=$ on\&utm term $=.560 \mathrm{f} 29 \mathrm{ac} 36 \mathrm{~d} 6$.

11. See Exec. Order No. 13,769, 82 Fed. Reg. 8,977 (Jan. 27, 2017); Exec. Order No. 13,767, 82 Fed. Reg. 8,793 (Jan. 25, 2017); Exec. Order No. 13,768, 82 Fed. Reg. 8,799 (Jan. 25, 2017). 
by illegal aliens" and "the problem of 'birth tourism,' whereby individuals travel for the purpose of giving birth in the United States." 12

The focus on these two issues reveals a troubling preoccupation with the rights of first-generation Americans born to immigrant parents - children that immigration hardliners derisively call "anchor babies." Indeed, this draft order foreshadowed the Administration's later moves to limit legal, family-based immigration; ${ }^{13}$ to question birthright citizenship $;{ }^{14}$ and, most overtly, to penalize immigrants of limited economic means as ultimately codified in the proposed rule on public charge.

These are unsurprising implementations of President Trump's nativist campaign rhetoric. As a private citizen and presidential candidate, Trump not only famously (and repeatedly) questioned the citizenship of his predecessor in office but also openly challenged the nationality of the U.S.-born children of immigrants. While many criticized Trump's birtherism theories about President Obama, few questioned his rhetoric delegitimizing birthright citizenship and millions of first-generation U.S. citizens. Similarly, neither the mainstream media nor lawmakers have paid much attention to now-President Trump's policies on public benefits and the impacts they would have on many immigrants (both documented and undocumented) or their U.S.-citizen children.

These proposed policies follow a familiar pattern in U.S. politics of invoking crude, race-based stereotypes to inform public debate and restrict public benefits use. Nineteenth century statutes, which limited migrations of poor people, and more recent efforts in the mid-1990s to expand the definition of public charge through welfare and immigration reform, laid the groundwork for the current Administration's policies. When examined together, these immigration policies on public charge bear striking similarities to the racist rhetoric that peaked in the '90s surrounding Black families' use of public benefits.

Despite the facial neutrality of Personal Responsibility and Work Opportunity Reconciliation Act of 1996 (the Welfare Act or PRWORA), many have criticized the Welfare Act's reliance on a racially discriminatory rhetoric. In particular, the figure of the "welfare queen" became a term of intense controversy as welfare reformers furthered the narrative of this

12. Memorandum from Andrew Bremberg, on a Draft of an Executive Order on Protecting Taxpayer Resources by Ensuring Our Immigration Laws Promote Accountability and Responsibility, to the President of the U.S., 4-5 (Jan. 23, 2017) (available at http://apps.washingtonpost.com/g/documents/national/draft-executive-orders-on-immigration/2315/).

13. Brian Bennett, Trump Says Chain Migration Allows 'Virtually Unlimited Numbers of Distant Relatives', L.A. TIMES (Jan. 30, 2018, 7:05 PM), https://www.latimes.com/politics/la-na-pol-essential-washington-updates-hold-trump-on-chain-migration-1517356312-htmlstory.html.

14. Julie Hischfeld Davis, President Wants to Use Executive Order to End Birthright Citizenship, N.Y. TiMES (Oct. 30, 2018), https://www.nytimes.com/2018/10/30/us/politics/trump-birthrightcitizenship.html. 
racially charged image as the personification of a system run amok. ${ }^{15}$ Many commentators have examined the evidence of racial bias permeating efforts to restrict welfare benefits. ${ }^{16}$ Yet, concurrent efforts to disqualify immigrants from welfare entitlements - as ultimately enshrined within the Welfare Act - have gone largely unexamined.

This Article likens the rhetoric surrounding the "welfare queen" to what the Author proposes as its immigrant counterpart, the "anchor baby." This comparison has been previously drawn in the area of political science, ${ }^{17}$ but this Article is the first in legal scholarship to analyze these potent stereotypes as conditions precedent to changes in law and policy against the perceived advances in legal rights achieved by Black and immigrant communities. While previous authors have argued that racially coded political rhetoric behind welfare legislation represents a racist backlash to the Civil Rights Act and greater societal inclusion of African Americans, this Article explores the context leading to exclusion of immigrant families within the push for welfare reform and other contemporaneous legislative campaigns.

In particular, this Article explores how anti-immigrant legislation1994's Proposition 187 in California and the federal Illegal Immigration Reform and Immigrant Responsibility Act of 1996 (IIRIRA) - framed the debate and attitudes around the deservedness of immigrants. By looking to a similar history of animus in the lead up to PRWORA's enactment, the Author argues that efforts to penalize and exclude immigrant access to welfare represent a nativist reaction to the Immigration and Nationality Act (INA) of 1965, and the increasingly diverse American population it fostered. While arguing that racist and nativist sentiments and rhetoric formed the basis for efforts to curtail receipt of public benefits, this Article also explores how the nineteenth century concept of the public charge has provided cover to welfare critics and allowed restrictions to immigrant families to go largely unexamined and free of widespread critique.

15. See Martin Gilens, Why Americans hate Welfare: Race, Media, and the Politics OF ANTIPOVERTY POLICY (1999); Wahneema Lubiano, Black Ladies, Welfare Queens, and State Minstrels: Ideological War by Narrative Means, in RACE-ING JUSTICE, EN-GENDERING POWER: ESSAYS on ANita Hill, Clarence Thomas, AND the Construction of Social Reality 323 (Toni Morrison ed., 1992); Kenneth J. Neubeck \& Noel A. Cazenave, Welfare Racism: Playing the Race CARd Against America's PoOr (2001); Dorothy Roberts, Killing the Black Body: RACE, REPRODUCTION, AND THE MEANING OF LiBERTY (1997); Catherine R. Albiston \& Laura Beth Nielsen, Welfare Queens and Other Fairy Tales: Welfare Reform and Unconstitutional Reproductive Controls, 38 How. L.J. 473, 476-78 (1995); Rosalee A. Clawson \& Rakuya Trice, Poverty As We Know It: Media Portrayals of the Poor, 64 PUB. OP. Q. 53, 53-64 (2000); Rose Ernst, Localizing the “Welfare Queen" Ten Years Later: Race, Gender, Place, and Welfare Rights, 11 J. GENDER RACE \& Just. 181, 183 (2008) (citing RoBERT M. ENTMAN \& ANDREW ROJECKI, THE BLACK IMAGE IN THE White Mind: MEDIA AND RACE IN AMERICA (2000)); Franklin D. Gilliam, The 'Welfare Queen' Experiment, NiEMAN REP., Summer 1999, at 52); Note, Dethroning the Welfare Queen: The Rhetoric of Reform, 107 HARV. L. REV. 2013, 2013 (1994).

16. Albiston \& Nielsen, supra note 15 , at $475-76$.

17. See Carly Hayden Foster, Anchor Babies and Welfare Queens: An Essay on Political Rhetoric, Gendered Racism, and Marginalization, 5 WOMEN, GENDER, \& FAMILIES OF COLOR 50, 51 (2017). 
Part I describes the historic development of public charge exclusion up to the appearance of the Welfare Act and IIRIRA in the mid-90s. Part I isolates a recurring pattern wherein the application of public charge exclusion inevitably responds to surges in immigration trends. Part II applies this history to examine the demographic, racial, and political context from which the Welfare Act emerged. Part II expands the work of critical race scholars on "welfare-queen" rhetoric to examine the co-occurring nativist impulses present in the Welfare Act's treatment of immigrants. Using this scholarship as a guide, welfare policy emerges as a majoritarian reaction to restrict minorities' societal ascendancy. The tendency to question eligibility for public benefits becomes a proxy for deciding who is rightfully "American." Nowhere does this become more evident than in the debate around birthright citizenship and the legitimacy of the "anchor baby." Part III applies the framework of the past to the current political moment and the calculated racism behind the immigration policies of the Trump Administration.

By localizing broader trends in immigration, and the political rhetoric that coincides with the expansion of public charge principles, the Article concludes that restrictions on public benefits ultimately have a greater relationship to race and ethnicity than to immigration or economic status. Historically, divisive political rhetoric against African American and immigrant communities represents a reaction against perceived social advances in these groups. In the immigrant experience, increased representation caused by higher levels of immigration trigger anti-immigrant political discourse, followed by changes in legal policy to curb public benefit eligibility. Understanding this blueprint for exclusion in the present daywith increasingly, overtly hostile rhetoric - allies and advocates can begin to subvert its power as a political tool. Movements can learn lessons from each other and interrupt formulaic and potent political attacks by comparing the struggles for racial, economic, and immigrant justice.

\section{POVERTY-BASED LEGAL RESTRICTIONS ON IMMIGRATION}

\section{A. Immigrants and the "Public Charge"}

Efforts to exclude immigrants ${ }^{18}$ based on their indigence have existed since before the founding of the United States. Even during a time when any limitation on immigration to the United States was practical and not yet legally prescribed, early colonialists employed the British common law

18. In this Article, I interchangeably use the terms "immigrant," "noncitizen," and "foreignborn" to refer to people who are not native-born, U.S. citizens. While immigration law collectively refers to these individuals as "aliens," I am persuaded by the work of Kevin Johnson and other immigration scholars that this term tends to dehumanize persons and promote the subjugation of their rights. See Kevin R. Johnson, Colloquium Proceedings: Panel One, "Aliens" and the U.S. Immigration Laws: The Social and Legal Construction of Nonpersons, 28 U. MiAMI INTER-AM. L. REV. 263, 264-67, 271-72 (1997). Thus, I employ that term only when making a direct quotation to other sources. 
practice of banishment of the poor from their communities. ${ }^{19}$ In the nineteenth century, tensions surrounding the arrival of immigrants from Ireland led to public support for increased control of Irish settlement and further institutionalized restrictions on the immigrant poor. ${ }^{20}$ The rise of nativist political movements and the stereotype of the Irish pauper led states and other locales to expand and develop the earlier common law practice ${ }^{21}$ of excluding and banishing the indigent.

By the late nineteenth century, the federal government had codified this practice in the Immigration Act of 1882 (the Act). ${ }^{22}$ The Act provided for the exclusion ${ }^{23}$ from the United States, of "any convict, lunatic, idiot, or any person unable to take care of himself or herself without becoming a public charge." 24 The federal adoption of the public charge ground of exclusion coincided with pitched anti-Chinese sentiment codified in the Chinese Exclusion Act of 1882 mere months before the passage of public charge exclusion. ${ }^{25}$ That law barred Chinese immigrants from becoming U.S. citizens or from legally immigrating to the United States and represented the race-conscious motivations behind early immigration restrictions. ${ }^{26}$ Later, the Immigration Act of 1903 extended the public charge determination to the deportation context, permitting removal of immigrants within two years of their arrival to the United States. ${ }^{27}$ Notably, this provision limited the public charge deportation grounds to "causes existing prior to landing"; thus, making the deportation ground essentially a failsafe on the "exclusion at entry" provision. With time, the public charge doctrine continued to develop with each iteration increasingly disfavoring immigrants. In 1907, the period for which an individual determined to be

19. See Hidetaka Hirota, Expelling the Poor: Atlantic Seaboard States and the NINETEENTH CENTURY ORIGINS OF AMERICAN IMMIGRATION POLICY 40 (2017).

20. Id.

21. Id. at 43 (discussing how British poor laws, and their practice of removing nonresidents from individual communities, constituted the first American efforts at a law of immigration control).

22. Immigration Act of 1882, ch. 376, § 2, 22 Stat. 214, 214; see also Ekiu v. United States, 142 U.S. 651, 659 (1892).

23. IIRIRA ushered in a number of profound changes in immigration law, a number of which I explore in this Article. One of the most fundamental changes was a shift in the overall framework for immigration enforcement. Prior to its passage, "exclusion" denoted the process by which noncitizens were denied entry into the U.S., while "deportation" defined the legal process for banishment from the U.S. for those already in the country. IIRIRA redefined that framework, converting exclusion into "inadmissibility" and deportation into "removal." While the terms changed, the new classifications remained the same in essential form and function to the previous processes. Throughout this Article, I refer to each process by the term historically relevant to the period I reference.

24. Immigration Act of 1882, ch. 376, § 2, 22 Stat. 214, 214. This was the first immigration statutory reference to "public charge" in federal immigration law. The statute built on the preexisting state-based efforts to banish the poor and established the principles developed in the years to follow. Together, those principles constitute what I refer to as public charge doctrine. In addition, I reference public charge law to refer to specific public charges statutes; and I refer to the public charge rule to describe a specific policy or regulation dealing with public charge.

25. Chinese Exclusion Act, ch. 126, 22 Stat. 58, 58-59.

26. See Gabriel J. Chin, Segregation's Last Stronghold: Race Discrimination and the Constitutional Law of Immigration, 46 UCLA L. Rev. 1, 7 (1998).

27. Act of Mar. 3, 1903, Pub. L. No. 57-162, ch. 1012, § 20, 32 Stat. 1213, 1218. 
a public charge extended from two years to three years. ${ }^{28}$ This change allowed officials more opportunity to detect and deport individuals on the grounds of being a public charge.

Despite the trend toward stringency, public charge law remained largely untouched for decades and became particularly rare as a ground of deportation or exclusion in the latter half of the twentieth century. ${ }^{29} \mathrm{Be}$ tween 1951 and 1984, public charge grounds accounted for only $0.6 \%$ of all people excluded from the United States and for a mere $0.06 \%$ of people deported between 1951 and $1980 .{ }^{30}$ Congress revived public charge law from near obsolescence in 1996 with two new pieces of federal legislation: the PRWORA and IIRIRA. ${ }^{31}$

\section{B. Immigration and PRWORA}

The decline in public charge immigration enforcement in the second half of the twentieth century coincides with a general downturn in immigration to the United States in those decades. By 1970 the overall foreignborn population hit its lowest point in the twentieth century at a mere $4.7 \%$ of the total population. ${ }^{32}$ This was a marked decrease from the turn of the century when the total foreign-born population reached a peak of $14.7 \%$ in $1910^{33}$ - the beginning of a decade where public charge accounted for nearly $33 \%$ of all deportations and over $50 \%$ of all exclusions. ${ }^{34}$ These numbers suggest that public charge enforcement has a directly proportional relationship to an increase in immigration. As immigration rates to the United States increase, the percentage of public charge exclusions and deportations also increase. By 1996 the immigrant population of the United States was again on the rise, having increased steadily from the 1970 s to account for $7.9 \%$ of the total population in $1990 .{ }^{35}$ By 2000 the immigrant population would jump to $11.1 \%{ }^{36}$ This increase in immigration coincided with a national political conversation on government welfare and the use of public benefits. Many scholars have examined the way in which race and gender played into these public attitudes about social safety net programs and calls for reform. ${ }^{37}$

\footnotetext{
28. Act of Feb. 20, 1907, Pub. L. No. 59-96, ch. 1134, § 20, 34 Stat. 898, 904-05.

29. U.S. Dep'T of Justice ImMigr. AND Naturalization SerV., 1996 Statistical YEARBOOK OF THE IMMIGRATION AND NATURALIZATION SERVICE 173, A.1-1, A.1-11, A.1-13, A.118, A.1-23-24 (1997).

30. Id. at 175,183 .

31. Id. at A1-23.

32. U.S. Immigration Population and Share Over Time, 1850-Present, MigRATION POL'Y INST., https://www.migrationpolicy.org/programs/data-hub/charts/immigrant-population-over-time (last visited Oct. 10, 2019) (follow "Number of Share of Total U.S. Population, 1850-2017" hyperlink under "By the Numbers: Current and Historical Stats about Immigrants at U.S. \& State Levels").

33. Id.

34. U.S. DEP'T OF JUSTICE, supra note 29 , at $175,183$.

35. U.S. Immigration Population and Share Over Time, 1850-Present, supra note 32.

36. Id.

37. See Joel F. Handler, "Constructing the Political Spectacle": Interpretation of Entitlements, Legalization, and Obligations in Social Welfare History, 56 BROOK. L. REV. 899, 935-36 (1990);
} 


\section{DeCONSTRUCTING ENTITLEMENTS THROUGH POLITICAL RHETORIC AND LEGISLATION}

\section{A. Racism, PRWORA, and the "Welfare Queen"}

Many commentators have exposed how neoconservatives used dogwhistle political appeals and thinly veiled racial stereotypes to shape social attitudes toward welfare target recipients of public benefits. A notorious political foil in these efforts was the "welfare queen." A stand-in for the undeserving poor, the "welfare queen" came to symbolize the quintessential urban freeloader taking advantage of government largesse and taxpayer dollars. Stories of Black mothers using government benefits to buy steaks and drive Cadillacs became political talking points and stoked white resentment to undermine federal welfare programs. Indeed, the racialized political rhetoric around welfare became so pervasive that civil rights advocate Marian Wright Edelman noted at the time how "[welfare has become] a fourth generation code phrase, perhaps more powerful than busing, quotas, and Willie Horton." 38

In 1990, UCLA Professor Joel F. Handler deconstructed the implications and assumptions by which political ideologies manipulate rhetoric around welfare. ${ }^{39}$ In a symposium examining the legacy of the 1970 landmark decision in Goldberg v. Kelly ${ }^{40}$ (in which the U.S. Supreme Court expressly recognized an individual's right and property interest in the receipt of government entitlements), ${ }^{41}$ Handler argues that welfare policy is both expressive and symbolic, "defin[ing] values and confirm[ing] status." 42 Because welfare policy is inherently concerned with societal status and values, Handler explains that line-drawing around policies of eligibility turn on, "[ $\mathrm{t}]$ he distinction between the deserving and undeserving poor," and that this distinction "is a moral issue that affirms the values of a dominant society by stigmatizing the outcasts." ${ }^{\prime 3}$ The expression of these in-group and out-group values is advanced through symbolism and language; "observers construct themselves by constructing Others." ${ }^{\text {"H }}$ Handler's theoretic framework for understanding welfare policy in the 1980s and 1990s as a process of expressing and regulating the values of the dominant society against "the Other" is useful in understanding the success of "welfare-queen" rhetoric. By creating symbolic language to describe the undeserving Other, the politically dominant group came to understand this

Kevin R. Johnson, Public Benefits and Immigration: The Intersection of Immigration Status, Ethnicity, Gender, and Class, 42 UCLA L. REV. 1519, 1519-25 (1995); Lucie E. White, No Exit: Rethinking

“Welfare Dependency” From a Different Ground, 81 GEO. L.J. 1961, 1966 (1993); Note, supra note 15 , at 2019 .

38. White, supra note 37, at 1966 n.22 (quoting Marian Wright Edelman).

39. Handler, supra note 37 at 899-900.

40. Id. at 899 .

41. 397 U.S. 254 (1970).

42. Handler, supra note 37 , at 926 .

43. Id. at 926 n.111 (quoting MurRay Edelman, Constructing the POLITICAL SpeCtaCle $17(1988))$.

44. Id. 
term to refer to Black mothers undeservedly receiving public assistance. This language was key to masking the reality that in 1991 the number of Black families receiving benefits roughly equaled the number of white families, despite the fact that the former were more likely to be living in poverty. ${ }^{45}$

Scholars have suggested that these race-based tropes found their origins in backlash to the civil rights movement. ${ }^{46}$ Anthony Cook argued that the conservative political attack on welfare of the 1980s, which culminated in the mid-1990s with the Welfare Act, was a white, political reaction to the Civil Rights Act of $1964 .{ }^{47}$ Cook suggested that revisions to political rhetoric and the rise of race-motivated, dog-whistle politics allowed neoconservatives to sublimate overtly racist policies into calls for limited government and welfare reform. ${ }^{48}$

Perhaps the most prominent proponent of these calls was President Ronald Reagan. Reagan used the issue of welfare fraud and abuse throughout his political career and garnered national attention to his pet project for policy reform in a 1976 presidential campaign rally: "In Chicago, they found a woman who holds the record' ... " [s] he used 80 names, 30 addresses, 15 telephone numbers to collect food stamps, Social Security, veterans' benefits for four nonexistent deceased veteran husbands, as well as welfare. Her tax-free cash income alone ha[d] been running $\$ 150,000$ a year." 49 Reagan lifted this anecdote from the criminal prosecution of a Black woman named Linda Taylor. ${ }^{50}$ Reagan's use of the Taylor story to illustrate welfare abuse effectively substituted the average welfare recipient with this extreme case of criminal intent and became a domestic policy talking point. $^{51}$

Reagan adopted welfare reform early into his political career, promising in the 1966 California gubernatorial race to send "the welfare bums back to work." 52 The timing of Reagan's rise to political prominence,

45. White, supra note 37 , at $1966 \mathrm{n} .20$ (noting that $38.1 \%$ of families receiving AFDC were white, while a marginally larger group (39.7\%) were African American).

46. While Anthony Cook explores this premise to argue that welfare reform signals a causal reaction to the Civil Rights Act, Joel Handler also notes the correlation between the political gains for African Americans brought about by the Act (including interest in welfare expansion) and a corresponding response of groups who "began attacking the welfare system." See Handler, supra note 37, at 956 ; see also infra note 47.

47. Anthony Cook, The Ghosts of 1964: Race, Reagan, and the Neo-Conservative Backlash to the Civil Rights Movement, 6 ALA. C.R. \& C.L. L. REV. 81, 82-83, 101-02, 114-15 (2015).

48. Id.

49. Josh Levin, The Welfare Queen, SLATE (Dec. 19, 2013, 12:41 AM), http://www.slate.com/articles/news_and_politics/history/2013/12/linda_taylor_welfare queen ronald reagan made her a notorious american villain.html.

50. Id.

51. Id. (explaining that the Chicago Tribune dubbed Linda Taylor with the notorious nickname in its coverage of the case).

52. Andrew Glass, California Republicans Nominate Reagan for Governor, June 7, 1966, POLITICO (June 7, 2017, 12:00 AM), https://www.politico.com/story/2017/06/07/california-republicans-nominate-reagan-for-governor-june-7-1966-239141. 
along with the strategies of the neoconservative movement, fall comfortably within the arc of response and backlash to the Civil Rights Act. Political strategist Lee Atwater infamously laid bare Republican efforts to capitalize on post-civil rights, white resentment in a 1981 interview outlining his "Southern strategy." In an epithet-laden explanation, then-White House staffer Atwater discussed how to apply racist policies for political gain by recasting and generalizing those issues in terms of economics: ${ }^{53}$

You start out in 1954 by saying, "[N-word], [n-word], [n-word]." By 1968 you can't say "[n-word]" - that hurts you, backfires. So you say stuff like, uh, forced busing, states' rights, and all that stuff, and you're getting so abstract. Now, you're talking about cutting taxes, and all these things you're talking about are totally economic things and a byproduct of them is, blacks get hurt worse than whites... "We want to cut this," is much more abstract than even the busing thing, uh, and a hell of a lot more abstract than "[N-word], [n-word].,"54

By the mid-1990s, the dog-whistle strategy had taken hold, with some Americans reflecting on welfare reform policy in overtly racist terms. Journalist Jason DeParle recalled receiving reader mail in response to his coverage of the welfare reform debate with comments including: "Dear Sir: What does it take before the liberal social reformers realize that 2000 years of civilziation [sic] has passed black people by," and "I as a middle class white person is paying for their children because the bloods can't keep it in their pants." ${ }^{55}$ These comments demonstrate how white voters had come to understand and heed the call of the dog-whistle politics surrounding welfare reform.

By 1996, the rhetoric finally became policy when the Republicancontrolled House and Senate put forth PRWORA (the Welfare Act). The Welfare Act created state block grants, implemented work requirements, and established "time out" limits to the periods for which recipients could receive benefits - prompting significant cuts to federal welfare programs. ${ }^{56}$ President Bill Clinton, who had pledged as a presidential candidate to "end welfare as we know it," signed PRWORA into law on August $22,1996 .{ }^{57}$ In the Rose Garden ceremony marking passage of the Act, Lillie Harden, a Black, former recipient of welfare and mother of three, introduced President Clinton and flanked him for the photo op in which he

53. Rick Perlstein, Exclusive: Lee Atwater's Infamous 1981 Interview on the Southern Strategy, NATION (Nov. 13, 2012), https://www.thenation.com/article/exclusive-lee-atwaters-infamous-1981interview-southern-strategy/.

54. Id. (the original quote was not sanitized by the euphemistic term, which I have bracketed here).

55. Jason DeParle, American Dream: Three Women, Ten Kids, AND A Nation's Drive TO END WELFARE 133 (2004).

56. Steven D. Schwinn, Toward a More Expansive Welfare Devolution Debate, 9 LEWIS \& Clark L. REV. 311, 312-13 (2005).

57. Bill Clinton, How We Ended Welfare, Together, N.Y. TIMES (Aug. 22, 2006), https://www.nytimes.com/2006/08/22/opinion/22clinton.html. 
signed PRWORA into law. ${ }^{58}$ Ms. Harden's remarks relating her move from welfare to work, seemed to be a White House effort to invoke and reject the "welfare-queen" label of the Reagan years. ${ }^{59}$

Yet, critics of the Act suggested that it played into racially coded and gendered stereotypes by emphasizing a family unit composed of two heterosexual married parents as key to economic security. Even without the profligate abuse invoked by the "welfare-queen" rhetoric of the 1980 s, the scapegoating of Black single mothers clearly informed the legislation and the political legacy leading up to PRWORA's passage. ${ }^{60}$ The Welfare Act's place in history - and the rhetoric that ultimately propelled its success - demonstrate how it represented a political and legislative response to the aspirations of the Civil Rights Act.

\section{B. Nativism, PRWORA, and the "Anchor Baby"}

A backlash to immigration also accounts for the anti-immigrant attitudes underlying federal legislation in the mid-1990s. Both PRWORA and IIRIRA formalized nativist anxieties following the rise of an increasingly diverse immigrant population. ${ }^{61}$ PRWORA disqualified even documented immigrants from a number of programs, and IIRIRA expanded the grounds of inadmissibility and removability that applied to them. ${ }^{62}$ IIRIRA accomplished these objectives, in part, by building on public charge inadmissibility. ${ }^{63}$

These limitations on immigrants' rights came at a time when the immigrant population was climbing. ${ }^{64}$ In 1991 , admissions for residence to the United States hit an all-time high, peaking at 1,826,595 new lawful permanent residents admitted. ${ }^{65}$ In addition to an increase in the number of immigrant arrivals, the demographics of the new residents changed markedly from previous decades. Of the total U.S. foreign-born population, European immigration steadily declined from $74.5 \%$ in 1960 to $15.8 \%$ in $2000 .{ }^{66}$ As the migration of white immigrants to the United States

58. Andrew Glass, Clinton Signs 'Welfare to Work' Bill, August 22, 1996, Politico (Aug. 22, 2018, 12:09 AM), https://www.politico.com/story/2018/08/22/clinton-signs-welfare-to-work-billaug-22-1996-790321; Barbara Vobejda, Clinton Signs Welfare Bill Amid Division, WASH. Post (Aug. 23, 1996), https://www.washingtonpost.com/wp-srv/politics/special/welfare/stories/wf082396.htm.

59. DEPARLE, supra note 55, at 398.

60. Cook, supra note 47 at 92, 114; Handler, supra note 37, at 936.

61. Audrey Singer, Welfare Reform and Immigrants - A Policy Review, in IMMIGRANTS, Welfare Reform, AND the POVERTY OF Policy 21, 26 (Philip Kretsedemas \& Ana Aparicio eds., 2004).

62. See Illegal Immigration Reform and Immigration Responsibility Act (IIRIRA), ch.5, sec. 341-52, 110 Stat. 3009 (1996) (codified as amended at 8 U.S.C. § 1182 (2006)).

63. IIRIRA $\S 531$.

64. Johnson, supra note 18, at 277-79, 282; Legal Immigration to the United States, 1820Present, MIGRATION POL'Y INST., https://www.migrationpolicy.org/programs/data-hub/charts/Annual-Number-of-US-Legal-Permanent-Residents? width $=850 \&$ height $=850 \&$ iframe $=$ true.

65. See Legal Immigration to the United States, 1820-Present, supra note 64.

66. Dara Lind, How the Immigration and Nationality Act Transformed America, In One Chart, Vox (Oct. 3, 2015, 4:00 PM), https://www.vox.com/2015/10/3/9446613/immigration-americachange. 
dropped off, immigration from other regions of the world steadily grew. ${ }^{67}$ In 1960, immigrants from the Americas (primarily Latin America) made up $19.1 \%$ of the total U.S. immigrant population with immigrants from Asia and Africa comprising 5\% and 0.6\%, respectively. ${ }^{68}$ By 1990 , those percentages increased to $46.3 \%$ from the Americas, $25.2 \%$ from Asia, and $1.8 \%$ from Africa. These changes in immigrant demographics would not have been possible without the 1965 INA. $^{.9}$

The INA fundamentally changed immigration demographics in two ways. First, the INA altered the use of immigration quotas, encouraging immigration from a more diverse set of countries worldwide. ${ }^{70}$ Second, the altered quota system impacted migration from Mexico by: (1) limiting the numbers of Mexican nationals, by quota, who could join family in the United States to a number exceeded by the demand for visas, and (2) ending the bracero program, which drew Mexican workers to the United States for seasonal work. ${ }^{71}$ Both of these changes fostered an increase in unauthorized immigration to the United States from Mexico. ${ }^{72}$ By the 1990 s, the unauthorized immigrant boom garnered national attention. ${ }^{73}$ Estimates suggested an increase in the undocumented population from 3.5 million in 1990 to 5.7 million in $1995 .^{74}$ This data emphasizes three main, distinguishing characteristics of immigration to the United States in the latter part of the twentieth century: (1) a growing immigrant population from the preceding decades, both in terms of raw numbers and percentage of the population; (2) an increasingly non-white immigrant population; and (3) a growing undocumented population. All of these factors played into the political rhetoric surrounding national immigration and welfare debates of the time.

As neoconservatives sought to malign public benefits recipients with "welfare-queen" rhetoric, a similar political language was developing to question the rights of the foreign-born. Tensions surrounding new arrivals, both documented and undocumented, led to increasingly stringent immigration laws and a renewed targeting of low-income immigrant families. Once again, nativist sentiments fueled a revisiting of the public charge doctrine. This time, lawmakers expanded the regulatory scheme surrounding public charge inadmissibility and tacked on criminal penalties related

\footnotetext{
67. Id.

68. Id.

69. Id.

70. Muzaffar Chishti, Faye Hipsman \& Isabel Ball, Fifty Years On, the 1965 Immigration and Nationality Act Continues to Reshape the United States, Migration POL'Y INST. (Oct. 15, 2015), https://www.migrationpolicy.org/article/fifty-years-1965-immigration-and-nationality-act-continuesreshape-united-states.

71. Id.

72. Id.

73. Cybelle Fox, Unauthorized Welfare: The Origins of Immigration Status Restrictions in American Social Policy, J. AM. HIST., 1051, 1052-53, 1073 (2016).

74. Jeffrey S. Passel \& D'Vera Cohn, As Mexican Share Declined, U.S. Unauthorized Immigrant Population Fell in 2015 Below Recession Level, PEW RES. CTR. (Apr. 25, 2017), http://www.pewresearch.org/fact-tank/2017/04/25/as-mexican-share-declined-u-s-unauthorized-immigrant-population-fell-in-2015-below-recession-level/.
} 
to welfare fraud. ${ }^{75}$ As with welfare reform, both Presidents Reagan and Clinton played an outsized role in passing laws that penalized immigrants.

\section{Historical Discrimination Behind Immigration-Status-Based Welfare Restrictions}

In the article Unauthorized Welfare: The Origins of Immigrant Status Restriction in American Social Policy, Cybelle Fox describes a federal government initially hesitant to restrict benefits based on immigration status. ${ }^{76}$ Fox explains how New Deal-era social programs made no distinctions between citizens and noncitizens, and that the current regime of status-based restrictions began at the state level between the 1930s and 1970s, eventually working its way through to federal policy. ${ }^{77}$ In 1971, the Supreme Court ruled in Graham v. Richardson ${ }^{78}$ that the Fourteenth Amendment's Equal Protection Clause protected noncitizens from alienage-based welfare restrictions. ${ }^{79}$ Many officials within the Nixon Administration interpreted the case to entitle even undocumented immigrants to public benefits and went so far as to circulate proposed regulations enshrining this view. ${ }^{80}$

While these officials never implemented the proposed rule, ${ }^{81}$ the permissive nature of the policy falls within a familiar pattern of inclusion and tolerance when viewed within the larger immigration context. Recall, the foreign-born population in 1970 fell to a historical low- $4.7 \%$ of the total U.S. population. ${ }^{82}$ European immigrants remained the dominant group of that time, accounting for nearly $60 \%$ of all immigrants. ${ }^{83}$ Fox describes how federal officials at the U.S. Department of Health, Education, and Welfare (HEW) - the federal agency then responsible for welfare-soon did an about-face on this policy and began to implement restrictions based on immigration status that would expand and continue to this day. ${ }^{84}$ These federal restrictions, beginning in the early 1970 s, came at a time of growing "economic malaise and racial tension." ${ }^{85}$ State efforts to limit immigrant welfare eligibility also informed the federal restrictions. Representatives from some of the southwest border states expressed the most vocal

\footnotetext{
75. See IIRIRA, ch.5, sec. 341-52, §531, 110 Stat. 3009 (1996) (codified as amended at 8 U.S.C. 1182 (2006)) (updating grounds for exclusion); IIRIRA. § 561 (increasing maximum criminal penalties for forging or counterfeiting seal of a federal department or agency to facilitate benefit fraud by an unlawful alien).

76. Fox, supra note 73 at $1051-74$.

77. Id.

78. 403 U.S. $365(1971)$.

79. Id. at $366,371,374,382-83$.

80. Fox, supra note 73, at 1052 .

81. Id.

82. Chapter 5: U.S. Foreign-Born Population Trends, Pew ReS. CTR. (Sept. 28, 2015), https://www.pewresearch.org/hispanic/2015/09/28/chapter-5-u-s-foreign-born-population-trends/; see also supra note 32 and accompanying text.

83. Regions of Birth for Immigrants in the United States, 1960-Present, MigRATION POL'Y INST., https://www.migrationpolicy.org/programs/data-hub/charts/regions-immigrant-birth-1960-present (last visited Oct. 10, 2019).

84. Fox, supra note 73 , at $1052-53$.

85. Id. at 1064 .
} 
opposition to the proposed regulation to extend federal benefits regardless of status. ${ }^{86}$

By 1970, Texas, with its "virulent history of anti-Mexican sentiment and institutionalized discrimination," was the only state that limited Aid to Families with Dependent Children (AFDC) and Medicaid to U.S. citizens. ${ }^{87}$ When the federal government weighed in with its regulation proposing immigration status-blind benefit eligibility, representatives from Texas presented some of the staunchest opposition to the new rule. ${ }^{88}$ Texas Republican Congressman James M. Collins derided the proposal, complaining that "[w]e are trying to develop a system of getting the Wetbacks under control and HEW has an incentive program of encouraging them to enter our country." 89

Meanwhile in California, five years before invoking the "welfarequeen" bogey, then-Governor Ronald Reagan approved the California Welfare Act of 1971. This law prevented "the granting of aid to illegal aliens and temporary foreign visitors." 90 Discriminatory sentiment also animated support for the California legislation. Before the passage of the California Welfare Act, one California columnist opined that, "California has long been known as a land of milk and honey. Its reputation is well known in Mexico, where to wetbacks ... the word is out: 'Go to California, where welfare workers hand out free food, free money and free medicaldental care just for the asking."

As these few states vocalized their strong opposition to the federal rule, and experimented with their own state-level restrictions, the federal government soon followed suit. In 1973, HEW officials scrapped the proposed status-blind eligibility rule and mandated restriction of welfare benefits to "a citizen or an alien lawfully admitted for permanent residence or otherwise permanently residing in the United States under color of law" (PRUCOL) ${ }^{92}$ This new PRUCOL doctrine officially disqualified undocumented immigrants and remained in place until Congress passed PRWORA. ${ }^{93}$

This debate around benefit eligibility and immigration status developed within a decade of the passage of the INA. The debate demonstrates

\footnotetext{
86. Id. at 1054 .

87. Id. at $1053,1066$.

88. Id. at $1065-66$.

89. Id. at 1067.

90. Id. at 1064 .

91. Id. at 1062 (quoting Mike Otten, "Illegal Aliens from Mexico Costing Taxpayers Millions", OXNARD PRESS COURIER, Oct. 29, 1970, at 4).

92. Id. at $1067-68$

93. See Personal Responsibility and Work Opportunity Reconciliation Act of 1996, Pub. L. No. 104-103, § 401, 110 Stat. 2105 (1996) (codified as amended at 8 U.S.C. § 1611 (2018)). Despite PRWORA's new approach to designating immigration eligibility status, PRUCOL remained in place and certain immigrants remained eligible under the earlier PRUCOL definition. See, e.g., 20 C.F.R. § 416.1618 (2019) (defining categories of individuals permanently residing in the United States under color of law for Supplemental Security Income benefits).
} 
how the backlash to greater immigrant inclusion began to materialize through increasing restrictions to welfare benefits. Policymakers and pundits used overtly racist language to justify restrictions with scant evidence that they were necessary. Indeed, many of these states came to find that administering status-based restrictions was cost prohibitive.

While many states created some alienage-based restrictions to New Deal federal programs in the 1930 s, within a decade many jurisdictions had already eliminated these requirements. ${ }^{94}$ States generally viewed these restrictions as too costly. ${ }^{95}$ States that eliminated these status-based eligibility grounds also happened to be places where the majority of immigrant groups were of European origin. ${ }^{96}$ Even in states where the immigrant population was majority Mexican, the cost of administering status-restricted benefits became a burden. In 1975, San Diego officials remarked that verifying immigration status "hardly justifie[d] the expenditure" after reviewing nearly 6,000 welfare cases and finding only ten undocumented immigrants on welfare. ${ }^{97}$ Given the great cost of status verification versus the exceeding rarity of ineligible noncitizens' use of benefits, it appears that bias informed these policies of restriction. Overtly racist rhetoric from those in the states applying these restrictions all but confirms this conclusion. ${ }^{98}$

In the decades that followed, the status restrictions established in the 1970s became the springboard for increasingly expansive limitations on immigrant benefit eligibility. While the PRUCOL standard initially only disqualified unauthorized immigrants, subsequent legislation imposed further restrictions on lawful immigrants' access to welfare. The Food Stamp Act of 1977 disqualified new, permanent residents from receiving meanstested benefits by "deeming" their immigration sponsors' incomes as their own. ${ }^{99}$ The Immigration Reform and Control Act of 1986 legalized nearly three million unauthorized immigrants ${ }^{100}$ but prohibited most of these lawful temporary residents from federal welfare programs. ${ }^{101}$ The Immigration Act of 1990 created TPS for nationals of countries plagued by natural

\footnotetext{
94. Fox, supra note 73, at 1056 (explaining that in 1939, twenty-five states and the District of Columbia had citizenship requirements, and an additional six had residency requirements for noncitizens only, but that ten states dropped these restrictions within ten years).

95. Id. at $1056-57$.

96. Id. at 1056 .

97. Id. at 1073 (noting that of that ten, all were technically eligible under California regulations).

98. Id. at $1072-73$.

99. Tanya Broder, State and Local Policies on Immigrants and Public Benefits: Responding to the 1996 Welfare Law, Clearinghouse ReV., Jan.-Feb. 1998, at 503, 504 n.7.

100. Muzaffar Chishti \& Charles Kamasaki, IRCA In Retrospect: Guideposts for Today's Immigration Reform, 9 MigRATION POLICY INSTITUTE ISSUE BRIEF, 2014, at 1, 6.

101. Memorandum for the Heads of Executive Departments and Agencies, 60 Fed. Reg. 7885 (Feb. 7, 1995).
} 
disaster or armed conflict ${ }^{102}$ but excluded them from welfare receipt by denying TPS holders the PRUCOL designation. ${ }^{103}$

Scholars have noted how immigrants' relative lack of political power, particularly the political vulnerability of the undocumented, contributed to the erosion of benefits in the last decades of the twentieth century. ${ }^{104}$ These authors have also suggested racial antipathy played a role in that lack of political will, especially as these efforts sought to disadvantage Latino immigrants.

In 1995, before PRWORA's passage, Kevin Johnson suggested that the efforts at immigrant benefit restriction were largely symbolic of growing ethnocentrism. ${ }^{105}$ Referencing the general absence of evidence of widespread benefit abuse (including data that immigrant use of public benefits roughly mirrors that of the native-born), Johnson suggested race and ethnicity are the primary political motivators behind these policies. ${ }^{106}$ In support of this argument, Johnson offered the case study of California's Proposition 187. ${ }^{107}$ Touted by proponents as the "Save Our State" or SOS initiative, the 1994 proposition promised to target unauthorized immigrants' use of public benefits and improve coordination with federal immigration enforcement. ${ }^{108}$ The most problematic section of Proposition 187 established an immigration status requirement for children's use of state-funded public education. ${ }^{109}$ An independent analysis, provided to California voters in advance of the vote on the initiative, warned voters of the likely unconstitutionality of the proposal; the analysis explained, "The U.S. Supreme Court has determined (in the case of Plyler v. Doe ${ }^{110}$ ) that excluding children who are illegal immigrants from public schools violates the federal constitution." "111 In addition to conflicting with constitutional law, the analysis explained how Proposition 187 had the potential to violate the federal Family Educational Rights and Privacy Act (FERPA) by requiring California schools to report children to immigration authorities without their parents' consent. ${ }^{112}$ Though the measure passed with nearly $59 \%$ of the vote, litigation on the constitutionality of the initiative immediately enjoined California officials from instituting its provisions. ${ }^{113}$

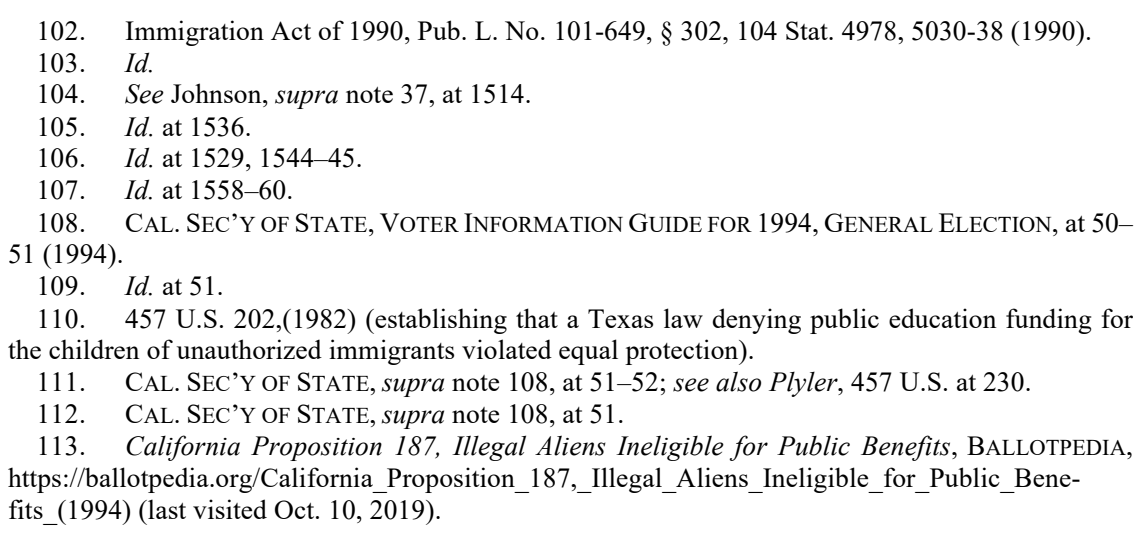


While the questionable, legal validity of Proposition 187 did not dissuade voters from approving the measure, concerns about more practical considerations also failed to sway support. The nonpartisan California Legislative Analyst estimated that taxpayers could expect to save \$200 million annually. ${ }^{114}$ Yet, the associated costs of the measure (including status verification across local agencies and loss of federal funding resulting from lack of compliance with federal law) would likely amount to several billion dollars. ${ }^{115}$ The electorate's willingness to vote against its own economic interest and rhetoric that condemned illegal immigrants ${ }^{116}$ suggested a biased motive in the passage of Proposition 187.

Previous authors have exposed the racial dynamics of Proposition 187 as a backlash to the increasing diversity in California and the United States. ${ }^{117}$ Few have compared the ways in which these nativist biases conspired to fundamentally change the nation's welfare system leading up to PRWORA. While the California proposal remained tied up in court, congressional legislators were working toward the construction of a bill that would ultimately disqualify many legally present immigrants from receipt of benefits. The experience of California was instructive, and federal efforts at welfare reform and immigrant eligibility trace their roots to the earlier popularity of Proposition 187. ${ }^{118}$ California's experiment paved the way for federal restrictions by suggesting that immigrants used more benefits than governments could sustain and blurring the distinctions between undocumented immigrants and legal immigrants. ${ }^{119}$ California also continued the legacy of the failed Texas legislation at issue in Plyler by targeting the children of immigrants. ${ }^{120}$ These efforts would conspire to eventually call into question the legitimacy not only of these children's entitlement to social programs but also to their acceptance for full citizenship.

During this time, the efforts of legislators in Sacramento and Washington, D.C. reflected a larger, race-conscious trend toward restrictions to social welfare programs in the Western world that corresponded with the increase in non-European immigration. ${ }^{121}$ But, unlike their state counterparts, federal lawmakers were able to point to an existing legal doctrine to "dress up" their racially-motivated legislation. The century-old public charge exclusion provided a convenient vehicle for justifying increased

\footnotetext{
114. CAL. SEC'Y OF STATE, supra note 108, at 52.

115. Id.

116. Id. at 54 ("We have to act and ACT NOW! On our ballot, Proposition 187 will be the first giant stride in ultimately ending the ILLEGAL ALIEN invasion.").

117. Ruben J. Garcia, Critical Race Theory and Proposition 187: The Racial Politics of Immigration Law, 17 CHICANO-LATINO L. REV. 118, 118 (1995); see generally Johnson, supra note 37, at 1544-47 (discussing Proposition 187 throughout and how the "changing demographics of immigration undoubtedly has contributed to the anti-immigration backlash").

118. Singer, supra note 61, at 25-26.

119. Id. at 26 .

120. Plyler v. Doe, 457 U.S. 202, 205 (1982).

121. Michael Bommes \& Andrew Geddes, Introduction: Immigration and the Welfare State, in IMMigRATION AND Welfare: CHALlENGING THE BORDERS OF THE Welfare STATE 1-12 (Michael Bommes \& Andrew Geddes eds., 2000).
} 
restrictions on immigrant use of antipoverty programs. The concept of public charge also served to mask some of the biased motivations targeting immigrant use of welfare that critics so roundly denounced in the contemporaneous debate around Black families' access to benefits.

Since then, racial and nativist sentiments against immigrants continued to build. No symbol has come to represent the hostility toward immigrants' perceived use of benefits more than the "anchor baby." While the public charge exclusion became the legislative pretext for racist restrictions on immigrant benefits, the image of the "anchor baby" has become the rhetorical device of choice for changes to welfare policy as it affects immigrants.

\section{The Policies and Politics of the "Anchor Baby"}

By the 1980s and '90s, efforts to restrict immigrant use of public benefits began to focus on the children of immigrants. States, like Texas in Plyler $^{122}$ and California with Proposition 187, passed legislation to restrict enrollment of undocumented children. Despite its then-limited role in administering public education, the federal government also restricted federal financial aid based on immigration status. ${ }^{123}$ Alienage restrictions of federal benefits to PRUCOL immigrants applied equally to children (documented and undocumented) and adults - restricting undocumented children from receiving these means-tested benefits as well.

Yet, as unauthorized immigration and the number of non-European immigrants climbed, nativist sentiments began to flare against a new target - the U.S.-citizen children of immigrants.

Like many of the efforts to disfavor immigrants' use of benefits, attempts to disqualify their U.S.-born children moved from the state to federal levels. In California, Governor Pete Wilson attempted to implement provisions of Proposition 187 by issuing an executive order directing that prenatal services to undocumented women "be discontinued as soon as legally possible." 124 Indeed, one of the most indignant points of the Proposition 187 proponents' arguments indicts the California State Legislature for "vot[ing] to continue free pre-natal care for ILLEGAL ALIENS! ${ }^{125}$ These excitable statements seemed to ignore that access to prenatal care is

122. Plyler, 457 U.S. at 205-06.

123. Higher Education Act of 1965, Pub. L. No. 89-329, § 484(a)(5), 79 Stat. 1219 (1965) (codified as amended at 20 U.S.C. $\S 1091$ (2018)) (limiting federal financial aid to U.S. citizens, lawful permanent residents, and those "able to provide evidence from the Immigration and Naturalization Service that he or she is in the United States for other than a temporary purpose with the intention of becoming a citizen or permanent resident.").

124. Paul Feldman \& Rich Connell, Wilson Acts to Enforce Parts of Prop. 187; 8 Lawsuits Filed: Immigration: The Governor Orders Prenatal Care Halted While a San Francisco Judge Bars Exclusion From School. O.C. School Administrators Promise Not to Report Children to Officials, L.A. TiMES (Nov. 10, 1994), http://articles.latimes.com/1994-11-10/news/mn-61147_1_school-administrators.

125. CAL. SEC'Y OF STATE, supra note 108, at 54. 
vital not only to the health of women but also critical to healthy development of children. ${ }^{126}$ Voters' willingness to support legislation that would harm these soon-to-be American citizens revealed a troubling hostility towards the U.S.-born children of immigrants.

After years of anti-welfare rhetoric, the election of a Republican congressional majority in 1994 finally made welfare reform possible. While the earlier scapegoating of Black families again contributed to reformers' calls for change, antagonism toward immigrants also informed the debate. Lynn Fujiwara explains how "[t]his majority rode in on a hostile anti-immigrant campaign that blamed liberal immigration policies for the visible influx of foreigners charged with burdening the American people through social costs." ${ }^{27}$ Even as welfare reform remained a top priority, congressional Republicans soon set their sights on immigration law. The 104th Congress drafted several bills designed to penalize immigrants and tighten immigration restrictions. ${ }^{128}$

The most successful of these was IIRIRA, which passed into law on September 30, $1996 .{ }^{129}$ In addition to its increased emphasis on immigration enforcement, the law complemented the welfare restriction in PRWORA by expanding the public charge grounds of exclusion and deportation (which under IIRIRA became "inadmissibility" for what in prior law was termed "exclusion" and "removal" for what was formerly "deportation"). ${ }^{130}$ In describing the interplay of 1996's welfare and immigration reforms, congressional historians explain how "the welfare legislation set new, more restrictive standards of eligibility, whereas the immigration bill provided the enforcement mechanisms for those standards."131

The anti-immigrant sentiment behind these legislative successes is perhaps most stark when viewed against other immigration proposals of the time. In 1991, twenty members of the 102nd Congress introduced H.R. 3605 , a bill to limit birthright citizenship to children born to "legal resident mothers." ${ }^{132}$ While this effort never made it out of committee, support for anti-immigrant federal legislation was gaining steam; three years later the

126. J. Rosenberg, Neonatal Death Risk: Effect of Prenatal Care is Most Evident After Term Birth, Guttmacher Inst.: PersP. ON SeXual \& Reprod. Health (Sept. 1, 2002), https://www.guttmacher.org/journals/psrh/2002/09/neonatal-death-risk-effect-prenatal-care-most-evident-after-term-birth (finding a $40 \%$ increase in the risk of neonatal death for women in the United States who have not received prenatal care).

127. LYNN FUJIWARA, MOTHERS WITHOUT CITIZENSHIP: ASIAN IMMIGRANT FAMILIES AND THE CONSEQUENCES OF WELFARE REFORM, at xiv (2008).

128. See infra notes $133-34$.

129. See James G. Gimpel \& James R. Edwards, JR., The Congressional Politics of IMMIGRATION REFORM 283 (1999).

130. Id. at 284; see also IIRIRA § 531 (a)(4)(B) (establishing new minimum criteria that immigration adjudicators must take into account for determining public charge disqualification).

131. Id.

132. H.R. 3605, 102d Cong. (1991) ("To amend the Immigration and Nationality Act to limit citizenship at birth, merely by virtue of birth in the United States to persons with legal resident mothers."). 
American people elected a Republican majority into the 104th Congress. ${ }^{133}$ In 1995, members of the House of Representatives introduced H.R. 1363, the Citizenship Reform Act. The Citizenship Reform Act proposed to restrict birthright citizenship to the children of U.S. citizens or lawful permanent residents. ${ }^{134}$ H.R. 2162, the Immigration Reduction Act of 1995, also proposed limiting automatic U.S. citizenship by birth while also reducing the number of immigrants who could be legally admitted into the United States. ${ }^{135}$

These initial efforts demonstrate some of the anti-immigrant attitudes of the congressional majority that passed welfare and immigration reform in the 104th Congress. They also reveal how immigration hardliners increasingly turned their attention to denying benefits to the children of immigrants. In fact, many House lawmakers supported an amendment to the immigration reform bill that would have overturned Plyler's promise of public education regardless of status. ${ }^{136}$ This provision narrowly avoided inclusion in the final bill following months of debate and under the threat of Bill Clinton's presidential veto power. ${ }^{137}$ These measures coincided with an increase in unauthorized immigration, ${ }^{138}$ a peak in the overall numbers in admission of legal immigrants, ${ }^{139}$ and the ongoing trend towards increased non-European immigration. ${ }^{140}$ In characterizing these policies, immigration restrictionists, again, turned to metaphor to craft their political rhetoric.

\section{Defining Birthright Citizenship and Who is "American"}

Birthright citizenship in the United States began with the common law application of jus soli, the conferring of citizenship rights based on birth within a designated territory. ${ }^{141}$ In the 1857 decision, Dred Scott $v$. Sandford,${ }^{142}$ the Supreme Court infamously placed a limit on this concept. The Court concluded that enslaved peoples of African descent failed to meet the federal definition of citizens of the United States:

133. See GIMPEL \& EDWARDS, JR., supra note 129, at 212-96.

134. Citizenship Reform Act of 1995, H.R. 1363, 104th Cong. (1995). The law also proposed a legitimacy standard whereby children could only acquire U.S. citizenship from a citizen or resident father within the bounds of marriage.

135. Immigration Reduction Act of 1995, H.R. 2162, 104th Cong. (1995).

136. See GIMPEL \& EDWARDS, JR., supra note 129, at 211-12, 273-74.The proposal, known as the Gallegly Amendment for its sponsor Republican Elton Gallegly of California, passed the House by a vote of 257 to 163 .

137. GIMPEL \& EDWARDS, JR., supra note 129, at 273-74.

138. Passel \& Cohn, supra note 74.

139. Legal Immigration to the United States, 1820-Present, supra note 64. The number reached 1,826,595 new permanent residents in 1991.

140. Regions of Birth for Immigrants in the United States, 1960-Present, supra note 83. Increased non-European migration accounted for $78 \%$ of the total immigration to the United States in 1990 and for $84.2 \%$ by 2000 .

141. Mariana E. Ormonde, Note \& Comment, Debunking the Myth of the "Anchor Baby": Why Proposed Legislation Limiting Birthright Citizenship is not a Means of Controlling Unauthorized Immigration, 17 ROGER WILLIAMS U. L. REV. 861, 862 (2012).

142. 60 U.S. 393 (1857). 
The question before us is, whether the class of persons described in the plea in abatement [enslaved peoples of African descent] compose a portion of this people, and are constituent members of this sovereignty? We think they are not, and that they are not included, and were not intended to be included, under the word 'citizens' in the Constitution, and can therefore claim none of the rights and privileges which that instrument provides for and secures to citizens of the United States. On the contrary, they were at that time considered as a subordinate and inferior class of beings, who had been subjugated by the dominant race, and, whether emancipated or not, yet remained subject to their authority, and had no rights or privileges but such as those who held the power and the Government might choose to grant them. ${ }^{143}$

It would take a Union victory in the Civil War, and the Fourteenth Amendment in 1868 , to refute the highly racialized legal proposition that birth in the United States was insufficient for conferring U.S. citizenship on non-white peoples. ${ }^{144}$ In the years that followed, increasing nativist sentiment led not only to public charge exclusion ${ }^{145}$ but also to race-based exclusions typified in the 1882 Chinese Exclusion Act. ${ }^{146}$

In August 1895, twenty-two-year-old Wong Kim Ark returned to the United States after a business trip to his parents' native China. ${ }^{147}$ U.S. immigration officials excluded him at entry, claiming that he was not a citizen of the United States despite his long-time residence and birth in California. ${ }^{148}$ In the resulting legal fight, the U.S. Supreme Court upheld Wong Kim Ark's U.S. citizenship. Applying the concept of jus soli, the Court held that: "The fourteenth amendment affirms the ancient and fundamental rule of citizenship by birth within the territory . . . includ[ing] the children born within the territory of the United States of all other persons, of whatever race or color, domiciled within the United States." 149

In addition to articulating the Fourteenth Amendment's racial nondiscrimination principle, the Court went on to confirm its equal application to children born in the United States regardless of their parents' alienage: "[E]very citizen or subject of another country, while domiciled here, is

\footnotetext{
143. Id. at 404-05.

144. See U.S. CONST. amend. XIV, § 1 ("All persons born or naturalized in the United States, and subject to the jurisdiction thereof, are citizens of the United States and of the state wherein they reside. No state shall make or enforce any law which shall abridge the privileges or immunities of citizens of the United States; nor shall any state deprive any person of life, liberty, or property, without due process of law; nor deny to any person within its jurisdiction the equal protection of the laws.").

145. See supra Part I.

146. Act of 1882, ch. 126, 22 Stat. 58 (1882), repealed by Chinese Exclusion Repeal Act of 1943, ch. 344, 57 Stat. 60 (1943).

147. United States v. Wong Kim Ark, 169 U.S. 649, 649 (1898).

148. Id.

149. Id. at 693 (finding certain exceptions to the general rule of birthright citizenship, including, "[C]hildren of foreign sovereigns or their ministers, or born on foreign public ships, or of enemies within and during a hostile occupation of part of our territory, and with the single additional exception of children of members of the Indian tribes owing direct allegiance to their several tribes").
} 
within the allegiance and the protection, and consequently subject to the jurisdiction, of the United States." 150

Wong Kim Ark established the legal precedent for the birthright citizenship of children born to noncitizen parents. ${ }^{151}$ Then, as in the mid1990s, the Court decided Wong Kim Ark during a time of increasing nativist backlash to immigrant settlement. Challenges to the citizenship of children born to noncitizen-parents gained momentum in the years following the 104th Congress's initial proposition to strip citizenship from the children of the undocumented. As the political right argued for limitations to birthright citizenship, the movement adopted a potent metaphor- the "anchor baby."

While the term had been used as early as the 1970s and 1980s to describe the U.S.-born children of Southeast Asian refugees, the figure of the "anchor baby" gained new currency in the later debate around illegal immigration. The moniker created a pithy shorthand to represent the issue conceptualized in lawmakers' attempts to limit birthright citizenship by statute. ${ }^{152}$ Namely, the nativist fear that immigrant women (and especially those without lawful immigration status) are seeking to give birth in the United States to secure the privileges of U.S. citizenship for their children and themselves. ${ }^{153}$ To quote Republican Congressman Bob Ehrlich of Maryland in 1997: "We want to take away your motivation to come to this country pregnant and have your baby." 154

\section{Birtherism, Executive Action on Immigration, and President Obama}

In the midst of the staggering anti-immigrant legislation of the mid1990s, the legislative effort to limit birthright citizenship captured little public attention. Restrictions in immigration law made it practically impossible for U.S.-citizen children to readily sponsor their undocumented parents for lawful permanent residence. IIRIRA's unlawful presence grounds of inadmissibility barred those in the United States without authorization from obtaining lawful permanent residence until they waited

150. Id

151. Id. at 693-94; see also He Famously Fought His U.S. Citizenship. Where Are His Descendants Now?, NPR (Oct. 2, 2015, 4:08 PM), https://www.npr.org/2015/10/02/445346769/he-famouslyfought-for-his-u-s-citizenship-where-are-his-descendants-now.

152. Amber Phillips, Is 'Anchor Baby' a Derogatory Term? A History of the Debate., WASH. Post (Aug. 20, 2015, 10:54 AM), https://www.washingtonpost.com/news/the-fix/wp/2015/08/20/isanchor-baby-a-derogatory-term-a-history-of-the-debate/?utm term=.ec11d75b5647.

153. Gabe Ignatow \& Alexander T. Williams, New Media and the 'Anchor Baby' Boom, $17 \mathrm{~J}$. COMPUTER-MEDIATED COMM. 60, 60 (2011).

154. Gyung-Ho Jeong, Congressional Politics of U.S. Immigration Reforms: Legislative Outcomes Under Multidimensional Negotiations, 66 POL. RES. Q. 600, 600-15 (2013). Ehrlich made these comments in reference to the so-called Gallegly Amendment, which would have denied public education to undocumented children. 
outside of the country for three or ten years. ${ }^{155}$ This disqualified many undocumented parents of U.S.-citizen children from pursuing legal status.

Yet, the misconception persisted that U.S.-born children would easily pass immigration status to their parents. In subsequent years, legislators would revisit the proposed Birthright Citizenship Act, reintroducing it in 2011 and again in 2017. ${ }^{156}$ By the 2000s, the rhetorical power of the "anchor baby" had begun to reach a prominence comparable to the effect created in earlier domestic policy debates around the "welfare queen." In 2006, the term "anchor baby" gained new currency in the renewed debate around immigration reform. ${ }^{157}$ That year, the editor of the American Heritage Dictionary of the English Language received a flurry of differing opinions on whether the term should include a label indicating it to be offensive (ultimately, the American Heritage did acknowledge the offensive connotation). ${ }^{158}$ A 2011 study also found a dramatic surge in the use of the term. ${ }^{159}$ The authors of the study focused on the news media and online sources; they found that "the term was used almost exclusively on extreme right-wing and anti-immigrant sites" in the early 2000s, but "by late in the decade it had appeared in almost all mainstream news outlets." 160

As with previous trends of in-group responses to minority inclusion, the proliferation of the term followed a marked shift in demographics and

155. Illegal Immigration Reform and Immigrant Responsibility Act of 1996, Pub. L. 104-208, 110 Stat. 3009, 576 (1996) (creating the Unlawful Presence Ground of Inadmissibility restricting lawful reentry to the United States for three years if the person has been in the country without authorization for more than 180 days, or for ten years if the person has been present without authorization for one year or more).

156. See Birthright Citizenship Act of 2017, H.R. 140, 115th Cong. (2017); see also Birthright Citizenship Act of 2011, H.R. 140, 112th Cong. (2011). Steve King, an Iowa Republican, introduced both bills, which are essentially the same in terms of content-both narrow the Fourteenth Amendment's meaning of "subject to the jurisdiction" of the United States to U.S. citizens and nationals, lawful permanent residences, and active duty service members. In early 2019, House Republican leaders sanctioned King for his comments to the New York Times that he did not understand why white supremacy is considered offensive. Trip Gabriel et al., Steven King Removed Form Committee Assignments Over White Supremacy Remark, N.Y. TIMES (Jan. 14, 2019), https://www.nytimes.com/2019/01/14/us/politics/steve-king-white-supremacy.html).

157. Phillips, supra note 152. In a fascinating coincidence with its role in diffusing the "welfare queen" moniker, the Chicago Tribune also played a part in the debate around the term "anchor baby," with columnist Eric Zorn facing criticism for his use of the term.

158. Id. Initially, the American Heritage defined the term as "[a] child born to a non-citizen mother in a country that grants automatic citizenship to children born on its soil, especially such a child born to parents seeking to secure eventual citizenship for themselves and other members of their family." Id. The definition was later updated to:

anchor baby

n.

Offensive

Used as a disparaging term for a child born to a noncitizen mother in a country that grants automatic citizenship to children born on its soil, especially when the child's birthplace is thought to have been chosen in order to improve the mother's or other relatives' chances of securing eventual citizenship.

Anchor baby, American Heritage Dictionary of the English Language, https://ahdictionary.com/word/search.html?q=anchor+baby (last visited Nov. 25, 2019).

159. Ignatow \& Williams, supra note 153 , at 60-61.

160. Id. at 60 . 
representations of people of color. By 2010, European immigration to the United States had dropped to $12.1 \%$ of all authorized immigration, ${ }^{161}$ and the undocumented population rose to an estimate of more than eleven million individuals. ${ }^{162}$

Notably, the popularity of the "anchor baby" archetype also coincided with the election of the nation's first Black president. The political backlash to Barack Obama's presidency has largely been understood as a racist reaction to the achievement of an African American in securing the nation's highest political office. Many of Obama's opponents applied rhetoric filled with nativist and xenophobic elements - regularly questioning the President's U.S. citizenship. This combination of race and nationality gave rise to the political conspiracy theory known as "birtherism."

Beginning with a 2004 suggestion by an Illinois political opponent that Obama was a secret Muslim, assertions that Obama was not born in the United States proliferated on the internet in the same way, and at the same time, as tirades against "anchor babies." "163 Obama's background as the son of a Black, Kenyan father and a white, U.S.-citizen mother incited racists and nativists. They questioned Obama's claim to the presidency and the validity of his American citizenship.

Among the many political opponents to question Obama's U.S. citizenship, none rose to greater prominence than Donald Trump. Trump launched his national political presence in 2011 by publicly questioning Obama's birthplace. ${ }^{164}$ In so doing, Trump sold a political product that the American electorate eagerly bought. A Gallup Poll from that time indicated that only $38 \%$ of respondents believed the President was "definitely" born in the United States. ${ }^{165}$ Trump's questioning of Obama's citizenship propelled him in the Republican 2012 presidential field to as high as a second place showing. ${ }^{166}$ Though Trump did not pursue the presidency in that election cycle, his foray into the political field set the stage for his 2016 run. It allowed him to experiment with the political rhetoric on citizenship and immigration that he would later deploy to characterize his domestic policy platform.

161. Regions of Birth for Immigrants in the United States, 1960-Present, supra note 83.

162. MigRATION POL'y INST., NATIONAL AND STATE ESTIMATES OF THE UNAUTHORIZED IMMIGRANT POPULATION, 2010 -2014, https://www.migrationpolicy.org/sites/default/files/datahub/State-County-Unauthorized-Estimates.xlsx.

163. Kyle Cheney, No, Clinton Didn't Start the Birther Thing. This Guy Did., Politico (Sept. 16, 2016, 3:55 PM), https:/www.politico.com/story/2016/09/birther-movement-founder-trump-clinton-228304.

164. Ashley Parker \& Steve Eder, Inside the Six Weeks Donald Trump Was a Nonstop 'Birther', N.Y. Times (July 2, 2016), https://www.nytimes.com/2016/07/03/us/politics/donald-trump-birtherobama.html.

165. Lymari Morales, Obama's Birth Certificate Convinces Some, But Not All, Skeptics, GalluP (May 13, 2011), https://news.gallup.com/poll/147530/obama-birth-certificate-convinces-not-skeptics.aspx.

166. Chris Cillizza, Trump Won't Run for President in 2012, WASH. Post (May 16, 2011), https://www.washingtonpost.com/blogs/the-fix/post/donald-trump-wont-run-for-president-in2012/2011/05/16/AF14G14G_blog.html?utm_term=.1fe9fba9648d. 
Trump's rhetoric also resonated with a conservative backlash to Obama that ultimately led to a Republican victory in the 2010 congressional elections. Early into their term, ninety Republican members of the newly formed 112th Congress joined to introduce H.R. 140 in early 2011. ${ }^{167}$ Dubbed the Birthright Citizenship Act of 2011, the proposal sought to limit U.S. citizenship by birth to children born to at least one parent who is a U.S. citizen, lawful permanent resident, or active duty member of the military. ${ }^{168}$ Though this version of the Birthright Citizenship Act enjoyed greater support than lawmakers' earlier attempts of the 1990 s, it too failed to make it out of the House of Representatives. ${ }^{169}$ Still, its occurrence under the new Republican congressional leadership, and on the heels of widespread conspiracies questioning Obama's nationality, demonstrates the reactive nature of this renewed anti-immigrant agenda. ${ }^{170}$ These animosities intensified as the Obama Administration embarked upon policies of greater inclusion for certain undocumented immigrants.

In 2012 the Obama Administration announced the DACA program. ${ }^{171}$ While Obama's aggressive immigration enforcement policy led to a record number of deportations, his use of deferred action to provide immigration relief to "dreamers" (undocumented youth with longtime residence in the United States who had been enrolled in school or the military) drew intense criticism from immigration restrictionists. ${ }^{172}$ Despite this, DACA attracted support from a variety of policymakers and hundreds of thousands of eligible youth applied for protection (which included work authorization and deferral of deportation) through the program.

Two years later, however, many immigration hardliners felt that the Obama Administration went too far. On November 20, 2014, Obama announced an executive action on immigration that would allow the parents of U.S. citizens and lawful permanent residents to qualify for protection similar to DACA recipients. ${ }^{173}$ This program, known as Deferred Action for Parents of Americans and Legal Permanent Residents (DAPA), ${ }^{174}$ for-

\footnotetext{
167. Birthright Citizenship Act of 2011, H.R. 140, 112th Cong. (2011).

168. Id

169. Id.

170. Amanda Sakuma, GOP Candidates Rethinking Constitution to End Birthright Citizenship, MSNBC (Aug. 8, 2019, 11:20 AM), http://www.msnbc.com/msnbc/gop-candidates-rethinking-constitution-end-birthright-citizenship.

171. See Memorandum from Janet Napolitano, Sec'y of Homeland Sec., to David V. Aguilar, Acting Comm'r, U.S. Customs \& Border Prot., et al. (June 15, 2012) (on file with U.S. Dep't Homeland Sec.) (formally announcing the DACA program).

172. See Julia Preston \& John H. Cushman, Jr., Obama to Permit Young Migrants to Remain in U.S., N.Y. TIMES (June 15, 2012), https://www.nytimes.com/2012/06/16/us/us-to-stop-deportingsome-illegal-immigrants.html (reporting on Congressman Steve King's intent on suing the Obama Administration to stop implementation of the DACA program).

173. 2014 Executive Actions on Immigration, U.S. CitiZenshiP \& IMMIGR. SERVS., https://www.uscis.gov/archive/2014-executive-actions-immigration (last updated Apr. 15, 2015).

174. See generally Deferred Action for Childhood Arrivals (DACA) and Deferred Action for Parents of American and Lawful Permanent Residents (DAPA), U.S. IMMIGR. \& CUSTOMS ENFORCEMENT, https://www.ice.gov/daca (last updated July 24, 2018).
} 
malized the fears of many immigration restrictionists that the undocumented would use their U.S.-born children to get a foothold into the United States.

Twenty-six states sued the Obama Administration to enjoin the program. ${ }^{175}$ The states, again, used the question of public benefits to argue that the program would cause them financial harm by requiring them to extend driver's licenses and unemployment benefits to beneficiaries of executive action. ${ }^{176}$ The states won; on June 23, 2016, the Supreme Court affirmed the decision of the Fifth Circuit Court of Appeals enjoining the implementation of DAPA. ${ }^{177}$ Government proposals to limit birthright citizenship and litigation to deny protections to parents of U.S. children during the Obama Administration created an atmosphere for stronger antiimmigrant rhetoric.

\section{PRESIDENT TRUMP'S EFFORTS TO LIMIT IMMIGRATION AND EXPAND PUBLIC CHARGE EXCLUSION}

The presidential campaign of Donald Trump conveyed the most overtly nativist and anti-immigrant tones in decades. When now-President Trump announced his run for the presidency he infamously honed in on the issue of immigration. He stoked fear of immigration and suggested that immigrants from Mexico were dangerous criminals:

When Mexico sends its people, they're not sending their best. They're not sending you. They're not sending you. They're sending people that have lots of problems, and they're bringing those problems with us. They're bringing drugs. They're bringing crime. They're rapists. And some, I assume, are good people. But I speak to border guards and they tell us what we're getting. And it only makes common sense. It only makes common sense. They're sending us not the right people. It's coming from more than Mexico. It's coming from all over South and Latin America, and it's coming probably - probably - from the Middle East. But we don't know. Because we have no protection and we have no competence, we don't know what's happening. And it's got to stop and it's got to stop fast. ${ }^{178}$

With this get-tough rhetoric, commentators observed that Trump has moved racially coded politics from a dog whistle to a "megaphone"179 or

175. See United States v. Texas, 136 S. Ct. 2271, 2271 (2016).

176. Texas v. United States, 809 F.3d 134, 149 (5th Cir. 2015) (arguing that the Obama Administration executive action on immigration violated the Administrative Procedures Act. The arguments around harm served to provide the states with legal standing to bring their lawsuits).

177. Texas, $136 \mathrm{~S}$. Ct. at 2271.

178. Here's Donald Trump's Presidential Announcement Speech, Time (June 16, 2015), http://time.com/3923128/donald-trump-announcement-speech/.

179. Michael D'Antonio, Trump's Racism has Gone from Dog-Whistle Bigotry to Megaphone Prejudice, CNN, https:/www.cnn.com/2018/01/12/opinions/trump-has-gone-from-dog-whistle-bigotry-to-megaphone-prejudice-opinion-dantonio/index.html (last updated Jan. 12, 2018). 
a "scream." ${ }^{180}$ Indeed, Trump's rhetoric against immigrants, especially immigrants of color, remains a defining characteristic of his campaign, presidency, and ultimately his appeal to his supporters. In addition to characterizing Mexican immigrants as drug dealers and rapists, Trump has used metaphor to suggest immigrants are viperous snakes. ${ }^{181}$ His views on race and immigration are clearly displayed in a reported exchange with lawmakers in which he suggested that immigration from "shithole countries" (reportedly regions in Central America and Africa) should be limited in favor of immigration from countries like Norway ${ }^{182}$ (whose population is of over $90 \%$ European origin). ${ }^{183}$ Trump even suggested that people of color are not citizens of the United States when he tweeted that four congresswomen of color-all U.S. citizens, and three of whom were born in the United States - should "go back and help fix the totally broken and crime infested places from which they came."184

Trump's rise occurred during a time when European immigration fell to a historic low. In 2016, immigrants born in Europe accounted for a mere $10.9 \%$ of all immigrants in the United States. ${ }^{185}$ Immigrants also accounted for $13.5 \%$ of the total U.S. population - a substantial percentage, comparable to the $13.3 \%$ immigrant population in the United States when the public charge exclusion first entered federal law in $1880 .{ }^{186}$

While many conservatives have argued that they have no issue with legal immigration, the Trump Administration has a different perspective. In addition to Trump's signature campaign promise to erect a wall at the U.S. southern border ${ }^{187}$ and enforce aggressive removal policies, ${ }^{188}$ the Trump Administration has overseen the dismantling of several immigration programs that permit immigrants to lawfully enter or remain in the United States. During his first week in office, President Trump issued an Executive Order banning nationals of several Muslim-majority countries regardless of their prior authorization for entry to the United States. ${ }^{189}$ The

180. Chris Cillizza, Donald Trump's Latest Dog Whistle on Immigration is More Like a Scream, CNN, https://www.cnn.com/2018/04/02/politics/donald-trump-daca-stolen/index.html (last updated Apr. 2, 2018).

181. Dara Lind, "The Snake": Donald Trump Brings Back His Favorite Anti-immigrant Fable at CPAC, Vox, https://www.vox.com/policy-and-politics/2018/2/23/17044744/trump-snake-speechcpac (last updated Feb. 23, 2018).

182. Cillizza, supra note 180.

183. Europe: Norway, CENT. INTELLIGENCE AGENCY (2017), https://www.cia.gov/library/publications/the-world-factbook/geos/no.html (last updated Oct. 2, 2019).

184. Laurie Kellman, A Look at the 'Squad' that Targeted Trump in Racist Tweets, ASSOCIATED PRESS (July 15, 2019), https://www.apnews.com/f80a96ce79934860936ebdc2127c28fc.

185. Regions of Birth for Immigrants in the United States, 1960-Present, supra note 83.

186. U.S. Immigration Population and Share Over Time, 1850-Present, supra note 32

187. Exec. Order No. 13,767, 82 Fed. Reg. 8793 (Jan. 25, 2017).

188. Exec. Order No. 13,768, 82 Fed. Reg. 8799 (Jan. 25, 2017).

189. Exec. Order No. 13,780, 82 Fed. Reg. 13,209 (Mar. 6, 2017). 
Trump Administration ended both of the Obama-era deferred action programs $;{ }^{190}$ ended TPS for a number of countries, ${ }^{191}$ halted a program that recruited immigrants with vital skills into the U.S. military; ${ }^{192}$ and proposed ending the current program of family-based ${ }^{193}$ and diversity immigration. ${ }^{194}$

In his campaign to limit authorized and unauthorized immigration alike, Trump found an important ally in his former Attorney General, Jeff Sessions. Sessions's support of Trump's immigration agenda included selective criminal prosecution of asylum seekers, ${ }^{195}$ separation of children from parents at the border, ${ }^{196}$ and the creation of legal precedent to limit claims for asylum from Central Americans fleeing gang-based and domestic violence. ${ }^{197}$ Prior to assuming the office of the attorney general, Sessions served as Senator for Alabama and an advisor to the Trump campaign. ${ }^{198}$ In an interview from his time on the campaign, Sessions pointed to the INA as the catalyst in creating an immigration surge. ${ }^{199}$ In response to this boom, Sessions advocated for significant restrictions on immigration. ${ }^{200}$ He suggested that the 1924 Johnson-Reed Act — which banned immigration across racial lines — was a useful legislative model. ${ }^{201}$

190. Tal Kopan, Trump Administration Reverses DAPA in 'House Cleaning', CNN, https://www.cnn.com/2017/06/16/politics/dhs-scraps-dapa-keeps-daca-deferred-action/index.html (last updated June 16, 2017) (noting that while DAPA was enjoined and never went into effect, the Trump Administration signaled its intention not to defend the program in further litigation); Trump Ends DACA, Calls on Congress to Act, NPR (Sept. 5, 2017, 9:05 AM) https://www.npr.org/2017/09/05/546423550/trump-signals-end-to-daca-calls-on-congress-to-act.

191. Jonathan Blitzer, The Battle Inside the Trump Administration Over T.P.S., NEW YORKER (May 11, 2018), https://www.newyorker.com/news/daily-comment/the-battle-inside-the-trump-administration-over-tps.

192. Sig Christenson, GI Kicked Out of Fort Sam to Become Citizen, SAN ANTONIO EXPRESSNEwS (Aug. 17, 2018), https://www.expressnews.com/news/local/article/GI-kicked-out-of-Fort-Samto-become-citizen-13164852.php.

193. Brian Bennett, Trump Says Chain Migration Allows 'Virtually Unlimited Numbers of Distant Relatives', L.A. TIMES (Jan. 30, 2018, 7:05 PM), http://www.latimes.com/politics/la-na-pol-essential-washington-updates-hold-trump-on-chain-migration-1517356312-htmlstory.html.

194. Trump Looks To Terminate The Diversity Lottery Program, NPR (Jan. 15, 2018, 4:57 AM), https://www.npr.org/2018/01/15/578083217/trump-looks-to-terminate-the-diversity-lottery-program.

195. Kate Morrissey, Sessions Promises Prosecution for All Illegal Border Crossings, Including Asylum Seekers, SAN DIEGO UNION-TRIB. (May 7, 2018, 7:20 PM), http://www.sandiegouniontribune.com/news/immigration/sd-me-sessions-visit-20180507-story.html.

196. Elliot Spagat, Sessions: Zero-Tolerance Policy May Split Families at Border, ASSOCIATED PRESS (May 7, 2018), https://www.apnews.com/f11e70e3d8c7424d8c0a01ae41ca15a7.

197. See In re A-B-, 27 I. \& N. Dec. 316, 320, 337-38 (2018).

198. Michael A. Memoli \& Brian Bennett, How Jeff Sessions Came to Be an Integral Part of Trump's Administration, L.A. TIMES (Mar. 2, 2017, 6:05 PM), https://www.latimes.com/politics/lana-pol-trump-sessions-20170302-story.html.

199. Adam Serwer, Jeff Sessions's Unqualified Praise for a 1924 Immigration Law, ATLANTIC (Jan. 10, 2017), https://www.theatlantic.com/politics/archive/2017/01/jeff-sessions-1924-immigration $/ 512591 /$.

200. Id. In calling for restrictions to immigration, Sessions praised the 1924 Johnson-Reed Act as an example and model of legislation to curb immigration. The 1924 Act was premised on the overtly racist premise to "end the "indiscriminate acceptance of all races." I $I$.

201. Id. 
Then-Senator Sessions also questioned birthright citizenship years before joining the Trump campaign. ${ }^{202}$ During a 2010 debate on whether to hold Senate hearings on the Fourteenth Amendment's citizenship clause, Sessions said, "People do not believe you should be able to break into America, have a baby and then the baby becomes a citizen, and the whole family says, 'We can't go home. My child is a citizen." "203 Prior to Trump's election, Trump also raised questions around the issue of birthright citizenship. However, his rhetoric went even further than his former attorney general's. Trump embraced the "anchor baby" term by refusing to back down from its use during the presidential campaign. ${ }^{204}$ And, while Sessions questioned the wisdom of jus soli, Trump questioned the validity of that citizenship all together: "I don't think they have American citizenship and if you speak to some very, very good lawyers - and I know some will disagree — but many of them agree with me and you're going to find they do not have American citizenship."205

Trump later revisited his controversial view of birthright citizenship once in office. Despite a chorus of opposition from legal scholars, Trump suggested in 2018 that he could end the right to U.S. citizenship "just with an executive order." ${ }^{206}$ By examining both men's past statements on the Fourteenth Amendment, a stunning conclusion emerges. While Sessions believes that children born in the United States to unauthorized immigrants should not be citizens, Trump believes they are not American citizens.

Knowing this context is key to understanding how the Trump Administration is seeking to change the rules on public charge. The Administration is deploying all measures available to turn back the clock on the racial diversity fostered by the INA and the symbolic inclusion of the Obama era. Through a number of programs, policies, executive actions, and racially charged, nativist rhetoric, the Administration has targeted immigrants and programs that support them.

Given similar past trends in American politics, it should come as no surprise that soon after Trump's inauguration in January 2017, the Trump Administration leaked the proposed Executive Order on "Protecting Taxpayer Resources by Ensuring Our Immigration Laws Promote Accountability and Responsibility." 207 As previewed in the introduction to this Article, the Order directed federal agencies to further restrict benefits to im-

202. Manu Raju \& Scott Wong, McCain Backs Citizenship Hearings, Politico (Aug. 3, 2010, 12:42 PM), https://www.politico.com/story/2010/08/mccain-backs-citizenship-hearings-040589.

203. Id.

204. Candace Smith, Jeb Bush, Donald Trump Unapologetic for 'Anchor Baby' Language, ABC NEws (Aug. 20, 2015, 4:52 PM), https://abcnews.go.com/Politics/jeb-bush-donald-trump-unapologetic-anchor-baby-language/story?id=33212138.

205. Jeremy Diamond, Donald Trump: Birthright Babies Not Citizens, CNN, https://www.cnn.com/2015/08/19/politics/donald-trump-birthright-american-citizenship/index.html (last updated Aug. 19, 2015).

206. Davis, supra note 14.

207. Hauslohner \& Ross, supra note 10. 
migrants by redefining guidance on public charge inadmissibility and deportability. ${ }^{208}$ Among the directives were proposals to expand the definition of a federal means-tested benefit for purposes of public charge determination and to rescind field guidance established for immigration adjudicators after the enactment of PRWORA and IIRIRA. ${ }^{209}$

While the Order was never officially adopted by the President, subsequent leaks confirmed that Administration officials were on their way to satisfying the Order's objectives. In early 2018, journalists obtained the leaked drafts of the proposed DHS regulations' outlining new rules on public charge. ${ }^{210}$ While the new rules did not impose an outright ban use of certain benefits, as Proposition 187 and PRWORA did, they sought to multiply the number of considerations that may lead to a public charge determination of inadmissibility or removal. ${ }^{211}$ The rule in the leaked draft would consider "whether any dependent family members for whom the alien provides financial support, including a U.S. citizen child, in the alien's household have received or are receiving public benefits." 212 This approach would have contradicted the 1999 INS Field Guidance on public charge, which addresses only the benefit use of the individual seeking admission or being charged with removability. ${ }^{213}$

The draft rule also expanded the benefits to be weighed in making a public charge determination. Because the benefits usage of immigrants' U.S.-citizen children were considered under the leaked draft, a number of programs for which immigrants themselves may not be eligible would be considered. This included programs such as Medicaid, Children's Health Insurance Programs, and Head Start. ${ }^{214}$ The draft policy also named subsidized healthcare and tax credits towards coverage under the Affordable Care Act as factors to be weighed in the public charge determination. ${ }^{215}$ By expanding the ways in which authorized and unauthorized immigrants could violate the public charge grounds of inadmissibility and deportability, the draft policy would have affected nearly 27 million people's use of public benefits. ${ }^{216}$ Of this staggering number, over 9 million would be U.S.-citizen children. ${ }^{217}$

\footnotetext{
208. See Hauslohner \& Ross, supra note 10; see also supra notes 1-17.

209. Hauslohner \& Ross, supra note 10.

210. Lind, supra note 2.

211. Id.

212. Id.

213. See Field Guidance on Deportability and Inadmissibility on Public Charge Grounds, 64 Fed. Reg. 28,689 (May 26, 1999).

214. Lind, supra note 2.

215. Id.

216. JEANNE BATALOVA, ET AL., supra note 5.

217. Id.
} 


\section{CONCLUSION}

While the DHS draft policies garnered media coverage that was somewhat muted in comparison to other Administration immigration policies, the leaks did serve to mobilize opposition. ${ }^{218}$ Coalitions of activists sought to challenge the efforts to expand public charge inadmissibility by garnering support from advocacy groups nationwide. ${ }^{219}$ These pressure tactics paid off.

When the government formally released its proposed rule for notice and comment on October 10, 2018, some of the provisions most closely directed at benefits received by children had disappeared. ${ }^{220}$ Yet, in the call for public comment to the proposed rule, the Government specifically requested comments on including benefits under the Children's Health Insurance Program (CHIP) in the public charge determination. ${ }^{221}$ Indeed, even without a more direct penalty to parents for their children's benefit use, the consequences anticipated by the government as recounted in the proposed rule include:

- Worse health outcomes, including increased prevalence of obesity and malnutrition, especially for pregnant or breastfeeding women, infants, or children, and reduced prescription adherence;

- Increased use of emergency rooms and emergent care as a method of primary health care due to delayed treatment;

- Increased prevalence of communicable diseases, including among members of the U.S.-citizen population who are not vaccinated;

- Increases in uncompensated care in which a treatment or service is not paid for by an insurer or patient; and

- Increased rates of poverty and housing instability; and

- Reduced productivity and educational attainment. ${ }^{222}$

To avert these dire consequences, a coalition of medical providers and activist groups committed to racial, social, and economic justice have campaigned against the proposed rule. ${ }^{223}$ This broad coalition of over 300

218. See, e.g., The PIF Campaign, ProteCting IMmigrant Families, https://protectingimmigrantfamilies.org/about-us/ (last visited Oct. 11, 2019).

219. NAT'L IMMIGR. L. CTR. \& CLASP, PROTECTING IMMigRANT FAMILIES, AdVANCING OUR FUTURE CAMPAIGN 3-4 (2019) (listing over 300 partner organizations nationwide mobilized in opposition to the proposed expansion of public charge inadmissibility).

220. Inadmissibility on Public Charge Grounds, 83 Fed. Reg. 51,114 (proposed Oct. 10, 2018) (to be codified at 8 C.F.R. pts. 103, 212, 213, 214, 245, \& 248).

221. 83 Fed. Reg. 51,173

222. Id. at 51,270 .

223. See NAT'L IMMIGR. L. CTR. \& CLASP, supra note 219. 
organizations reflects diverse interest groups that have experienced government attacks on public benefits as examples of systemic racism. DHS received hundreds of thousands of public comments in response to its notice of proposed rulemaking on public charge inadmissibility. ${ }^{224}$ When DHS promulgated the final rule in August of 2019, dozens of litigants, representing states, localities, and private organizations and individuals, sued to enjoin the scheduled implementation of the rule. ${ }^{225}$ In at least three of these challenges, the plaintiffs have claimed that the new public charge rule is a racially discriminatory violation of the Equal Protection Clause of the Fourteenth Amendment. ${ }^{226}$ While the courts hearing these challenges declined to rule on the merit of the equal protection claims, they did ultimately find that the new rule likely violated the Administrative Procedures Act - the plaintiffs' primary cause of action. ${ }^{227}$ Still, that the plaintiffs in these cases advanced this novel claim based on discrimination against non-white immigrants is remarkable. It is particularly historic that California - the state made infamous by Proposition 187-was one of the litigants to advance the equal protection litigation strategy along with other localities and a number of healthcare and legal services providers. ${ }^{228}$

These new political alliances represent a sense of shared purpose among minority groups and immigrants that seemed impossible in the 1990s when the debate on welfare reform largely ignored the interests of noncitizens. It is also stunning to see many states - the laboratories of discrimination where many anti-immigrant public benefits policies fist originated-join in the effort to curb the expansion of the public charge rule. Today, an understanding of intersectionality and the predictable consequences of conservative political attacks on communities of color have equipped advocates to work across interest groups and join forces to challenge these anti-immigrant proposals. By understanding tired political attacks on "welfare queens," activists are poised to disrupt and subvert antiimmigrant political rhetoric on "anchor babies." In their efforts, activists must understand public charge exclusion as a discriminatory, racially motivated policy. Current policymakers' overtly biased rhetoric also make expansions to public charge more vulnerable to legal challenge. The combination of these legal tools in the hands of a diverse group of stakeholders makes this expansion of the public charge rule less likely to succeed than

224. Inadmissibility on Public Charge Grounds, supra note 7.

225. See Cook Cty. v. McAleenan, No. 1:19-cv-06334 (E.D. Ill. Oct. 14, 2019) (order granting preliminary injunction); CASA de Md. Inc. v. Trump, No. 8:19-cv-02715-PWG (S.D. Md. Oct. 14, 2019) (order granting preliminary injunction); New York v. Dep't of Homeland Sec., No. 1:19-cv07777-GBD (S.D.N.Y. Oct. 11, 2019) (order granting preliminary injunction); City \& Cty. of S.F. v. U.S. Citizenship \& Immigration Serv., No. 4:19-cv-04717-PJH (N.D. Cal. Oct. 11, 2019) (order granting preliminary injunction); Wash. v. U.S. Dep't of Homeland Sec., No. 4:19-CV-5210-RMP (E.D. Wash. Oct. 11, 2019) (order granting preliminary injunction).

226. CASA de Md. Inc., No. 8:19-cv-02715-PWG; U.S. Citizenship \& Immigration Serv., No. 4:19-cv-04717-PJH; U.S. Dep't of Homeland Sec., No. 4:19-CV-5210-RMP.

227. See supra note 225 and accompanying text.

228. See supra note 226 and accompanying text (the Court joined the State of California's suit to similar actions filed by the City and County of San Francisco, and another group led by the organization La Clinica de la Raza). 
[Vol. 97:1

in earlier iterations. Understanding this history shows not only that there is a moral imperative to prevent its expansion but also that activists must partner to use law and policy to end the public charge rule and return it to the nineteenth century from which it came.

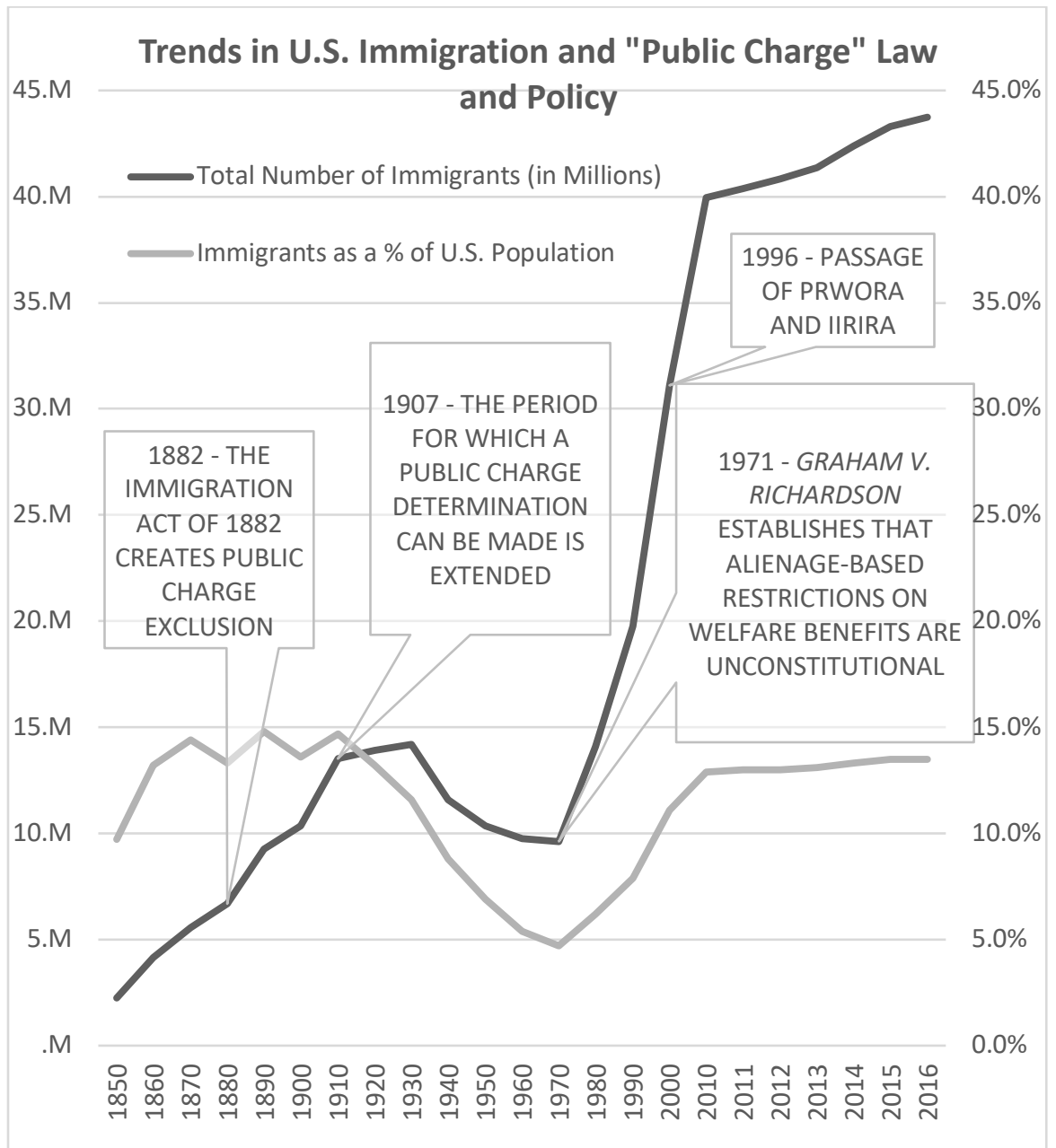

Figure $1 .{ }^{229}$ Chart comparing immigration flows to changes in public charge and welfare policy for immigrants

229. Migration Data Hub, MigRATION POLICY InST., https://www.migrationpolicy.org/programs/migration-data-hub (last visited Oct. 11, 2019) (applying historical statistics from USCIS). Callout boxes added by the Author. 